NIST Special Publication 1235

\title{
Summary of Workshop on Global Overview of Large Outdoor Fire Standards
}

Organized in Conjunction with ISO TC92 Task Group 03

Samuel L. Manzello

This publication is available free of charge from: https://doi.org/10.6028/NIST.SP.1235

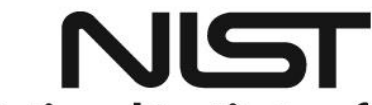

National Institute of Standards and Technology U.S. Department of Commerce 
NIST Special Publication 1235

\section{Summary of Workshop on Global Overview of Large Outdoor Fire Standards}

Samuel L. Manzello

Fire Research Division

Engineering Laboratory

This publication is available free of charge from: https://doi.org/10.6028/NIST.SP.1235

February 2019

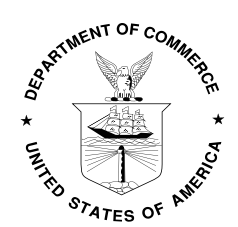

U.S. Department of Commerce Wilbur L. Ross, Jr., Secretary 
Certain commercial entities, equipment, or materials may be identified in this document in order to describe an experimental procedure or concept adequately. Such identification is not intended to imply recommendation or endorsement by the National Institute of Standards and Technology, nor is it intended to imply that the entities, materials, or equipment are necessarily the best available for the purpose.

The content of the oral presentations reproduced in this workshop report are those of the authors and do not necessarily represent NIST's perspective.

National Institute of Standards and Technology Special Publication 1235

Natl. Inst. Stand. Technol. Spec. Publ. 1235, 33 pages (February 2019)

CODEN: NSPUE2

This publication is available free of charge from: https://doi.org/10.6028/NIST.SP.1235 


\begin{abstract}
Large outdoor fires have the potential to negatively impact the built environment. Wildland fires that spread into communities, known as wildland-urban interface (WUI) fires, have become a global problem. Large urban fires, including those that have occurred after earthquakes, are another example of large outdoor fires. Once a WUI fire reaches a community, a large urban fire may develop. Presentations were delivered related to national and regional summaries from across the globe of large outdoor fire standards intended to make communities less vulnerable to these fires. Understanding from these national and regional summaries will be used as a basis for future standardization work on this topic in ISO TC92.
\end{abstract}

\title{
Key words
}

Large Outdoor Fires; Urban Fires; Wildland-Urban Interface (WUI) Fires 


\section{Table of Contents}

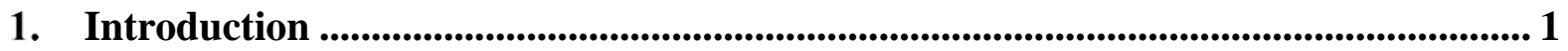

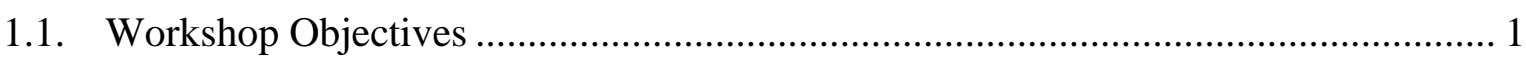

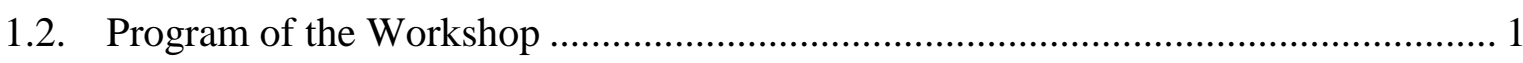

1.3. List of Registered Participants (Alphabetical Order) ............................................ 2

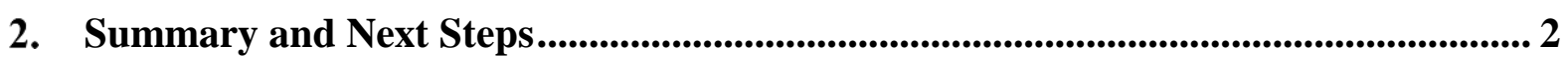

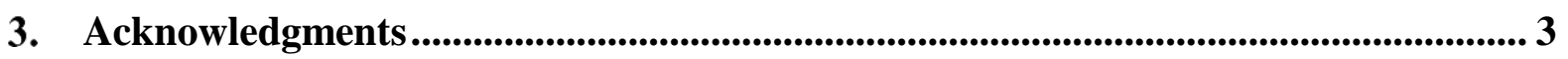

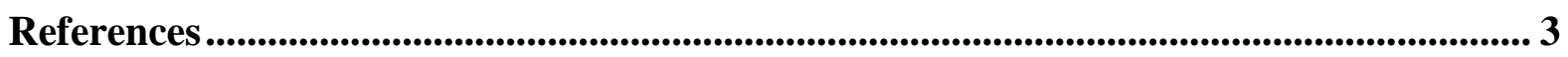

Appendix A: List of Presentations Delivered at the Workshop ........................................ 4 


\section{Introduction}

\subsection{Workshop Objectives}

Large outdoor fires have the potential to negatively impact the built environment. Wildland fires that spread into communities, known as wildland-urban interface (WUI) fires, have become a global problem. Large urban fires, including those that have occurred after earthquakes, are another example of large outdoor fires. Once a WUI fire reaches a community, a large urban fire may develop. Presentations were delivered related to national and regional summaries from across the globe of large outdoor fire standards intended to make communities less vulnerable to these fires. Understanding from these national and regional summaries will be used as a basis for future work on this topic in ISO TC92.

\subsection{Program of the Workshop}

Welcome/Goals/Objectives (9:00 am)

Samuel Manzello, National Institute of Standards and Technology (NIST), ISO TC92 TG03 Convener, USA

Current Wildland-Urban Interface (WUI) Building Codes and Standards in the USA (9:40 am) Daniel Gorham and Stephen Quarles, Insurance Institute for Business \& Home Safety (IBHS), USA

A Review of Design Guidance on Wildland-Urban Interface (WUI) Fires (10:00 am)

Paolo Initini, Lund University, Sweden and Polytechnic University of Bari, Italy

Enrico Ronchi, Lund University, Sweden

Steven Gwynne and Noureddine Bénichou, National Research Council, Canada

Wildland-Urban Interface (WUI) Fires in Spain: Summary of the Policy Framework and Recommendations for Improvement (10:20 am)

Elsa Pastor, Universitat Politècnica de Catalunya-Barcelona Tech (UPC), Spain

Large Urban Fires in Japan - History and Management (10:40 am)

Hideki Yoshioka, National Institute for Land and Infrastructure Management (NILIM), Japan Keisuke Himoto, National Institute for Land and Infrastructure Management (NILIM), Japan Koji Kagiya, Building Research Institute (BRI), Japan

Takeyoshi Tanaka, Kyoto University, Japan

Regulatory Controls for Buildings in Bush-fire Prone Areas in the Oceania Region (11:00 am) Greg Baker, Olsson Fire \& Risk, New Zealand

Alex Webb, CSIRO Infrastructure Technologies, Australia

Peter Whiting, BRANZ Ltd, New Zealand

Concluding Remarks/Next Steps

Samuel Manzello, National Institute of Standards and Technology (NIST), ISO TC92 TG03 Convener, USA 


\subsection{List of Registered Participants (Alphabetical Order by Surname)}

Alfredo Arnedo (SENER, Spain)

Noureddine Bénichou (National Research Council, Canada)

Jungmin Choi (Fire Insurers Laboratories of Korea, Korea)

Horacio Colina (ATILH, France)

Rita Fahy (National Fire Protection Association, USA)

Daniel Gorham (Insurance Institute for Business \& Home Safety, USA)

Eric Guillaume (Efectis, France)

Tetsuya Hayakawa (TSV, Japan)

Yoshihiro Hase (Mitsubishi Chemical, Japan)

Kazunori Harada (Kyoto University, Japan)

Patrick van Hees (Lund University, Sweden)

Anja Hofmann (BAM, Germany)

Paolo Intini (Lund Unversity, Sweden/Polytechnic University of Bari, Italy)

Koji Kagiya (Building Research Institute, Japan)

Yangkyun Kim (Korea Institute of Civil Engineering and Building Technology, Korea)

Samuel Manzello (National Institute of Standards and Technology, USA)

Brian Meacham (Meacham Associates, USA)

Tensei Mizukami (National Institute for Land and Infrastructure Management, Japan)

Hirokazu Murohoshi (IIBH, Japan)

Tomohiro Naruse (National Institute for Land and Infrastructure Management, Japan)

Kyriakos Papaioannou (Aristotle University, Greece)

Elsa Pastor (Universitat Politècnica de Catalunya-Barcelona Tech, Spain)

John Roberts (LRI Engineering, Canada)

Enrico Ronchi (Lund University, Sweden)

Yichul Shin (Fire Insurers Laboratories of Korea, Korea)

Benoit Smerecki (AFNOR, France)

Joseph Su (National Research Council, Canada)

Junichi Suzuki (National Institute for Land and Infrastructure Management, Japan)

Manuela Tancogne-Dejean (ATILH, France)

Yongho Yoo (Korea Institute of Civil Engineering and Building Technology, Korea)

Hans van de Weÿgert (IFC, UK)

Colleen Wade (BRANZ, New Zealand)

Elizabeth Weckman (University of Waterloo, Canada)

Jürgen Weise (Halfkann Kirchner, Germany)

Hideki Yoshioka (National Institute for Land and Infrastructure Management, Japan)

\section{Summary and Next Steps}

A total of 35 global experts participated, representing Canada, France, Germany, Greece, Italy, Japan, Korea, New Zealand, Spain, Sweden, United Kingdom, and USA. The workshop was organized to further explore the justification of activities in ISO TC92 for this topic, and how to properly align it in the organization of TC92. Presenters were asked to highlight gaps and specific standards needs in their regions.

Manzello (NIST, ISO TC92 TG03 convener, USA) kicked-off the workshop and presented the TG03 roadmap that was sent to all TC92 members on December, 2017 (3-month open comment period until March, 2018). Again, this roadmap motivated the need for the workshop. As part of the opening presentation, Manzello discussed the newly approved 
International Association for Fire Safety Science (IAFSS) permanent working group on Large Outdoor Fires and the Built Environment [1] and also presented the recent paper he developed for the International FORUM of Fire Research Directors [2], on Wildland-Urban Interface (WUI) fires, a part of Large Outdoor Fires and the Built Environment. The IAFSS working group is bringing the full depth of knowledge of the entire IAFSS community to the large outdoor fire problem. Mr. Daniel Gorham (IBHS, USA) presented an overview of USA codes and standards focused on WUI fires. Mr. Gorham discussed some specific IBHS research, with firebrand ignition being a need to address current gaps in USA codes and standards.

Dr. Paolo Intini (Lund University, Sweden/Polytechnic University of Bari, Italy) presented an overview of WUI codes and standards across multiple continents. Gaps and inconsistencies in global WUI codes and standards were the focus of his presentation. Dr. Elsa Pastor (Universitat Politècnica de Catalunya, Spain) presented an overview of the WUI situation in Spain, highlighting current standards and codes shortcomings in Spain. Dr. Hideki Yoshioka (NILIM, Japan) presented an overview of the large outdoor fire and the built environment situation in Japan. His presentation focused on large urban fires, common in Japan, and another component to the large outdoor fire and the built environment problem. Dr. Greg Baker (Olsson Fire \& Risk, New Zealand) presented remotely (unable to come) and provided an overview of bushfire standards and codes in the Oceania region.

Manzello (NIST, ISO TC92 TG03 Convener, USA) closed the workshop and indicated a special section will be developed for the journal Fire Technology, as presenters will prepare papers. Finally, the audience was queried for new suggestions for potential Work Items (WI) in the event a new Working Group is formed under ISO TC92 on this topic. The current TG03 roadmap, that was presented, has many potential WI, and TG03 will prioritize these.

\section{Acknowledgments}

The support of the Netherlands Standardization Institute, known as NEN, is greatly appreciated as the local host for the ISO TC92 meetings. In particular, SLM would like to thank Dr. Rob Kotte of NEN for his support in setting up this workshop at the Westcord Hotel in Delft. Dr. Enrico Ronchi (Lund University, Sweden), Dr. Mohamad El Houssami (Plastics Europe, France), and Dr. Nourredine Bénichou (NRC, Canada) are appreciated for volunteering as the organizing committee on behalf of TG03.

\section{References}

[1] S.L. Manzello, S. McAllister, and S. Suzuki, Large Outdoor Fires and the Built Environment: Objectives and Goals of Permanent IAFSS Working Group, Fire Technology, 54:579-581, 2018.

[2] S.L. Manzello, K. Almand, E. Guillaume, S. Vallerent, S. Hameury, and T. Hakkarainen, FORUM Position Paper, The Growing Global Wildland Urban Interface (WUI) Fire Dilemma: Priority Needs for Research, Fire Safety Journal, 100:64-66, 2018. 
Appendix A: List of Presentations Delivered at the Workshop 
ISO TC 92 Task Group 3

Dr. Samuel L. Manzello, Leader Fire Research Division

National Institute of Standards and Technology (NIST), USA Invited Guest Researcher

Building Research Institute (BRI), Japan

National Research Institute of Fire and Disaster (NRIFD), Japan samuelm@nist.gov
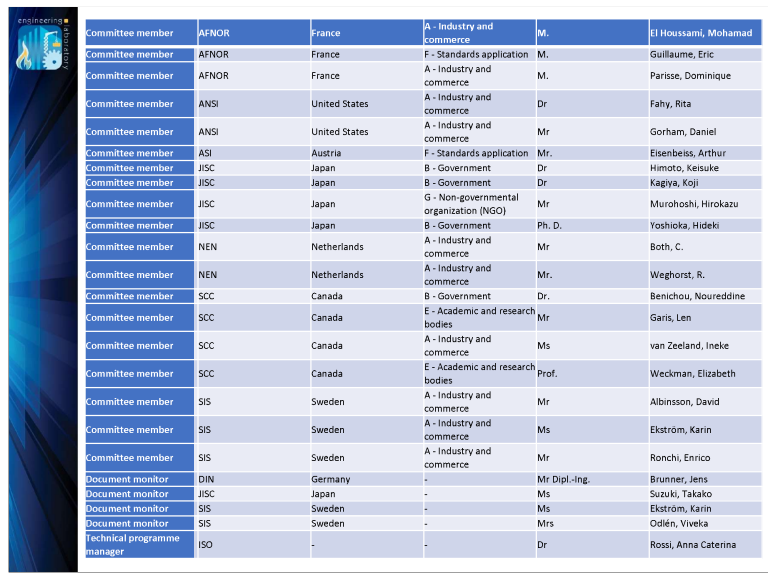

ISO TC 92

Task Group 3

Current Roster

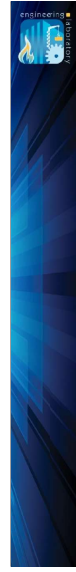

Global Standardization Roadmap for ISO TC92

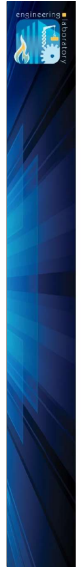

\section{Roadmap}

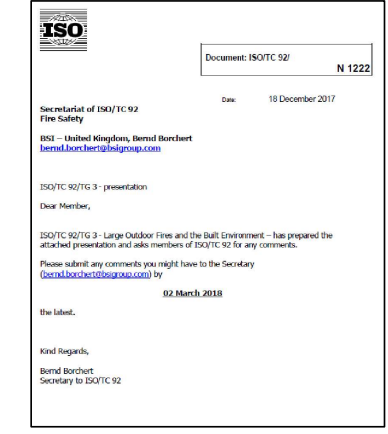

Roadmap was put in

presentation format

to be easily digested!
No negative comments

\section{Global Standardization Needs Revelop: \\ Large Outdoor Fires and the Built Environment \\ Balloted December 2017; Closed March 2018}

Wildfires that spread into communities, known as Wildland-Urban Interface (WUI) fires have destroyed communities throughout the world

- Large outdoor fires that pose risk to built environment are urban fires in Japan

\section{Large Outdoor Fires and the Built Environment}

- WUI fire problem important in Canada, France, Portugal, Spain, Italy, and Greece, Chile, Argentina, Brazil, and Australia

- USA:

- An average of 75,000 wildland fires consumes a total of 7 million acres of forest land on average each year

- Roughly, $2-3 \%$ of these fires spread into adjacent urban areas, resulting in an average loss of approximately 3000 homes

- Seven of the fifteen largest U.S. fire loss incidents in this period were WUI fires, with an average property value dollar loss of $\$ 1.4$ billion - does not Colude recent California fires

- Concurrently, the U.S. WUI areas continue to grow; at least 46 million structures are located in these areas comprising over 70,000 communities and affecting 120 million people 

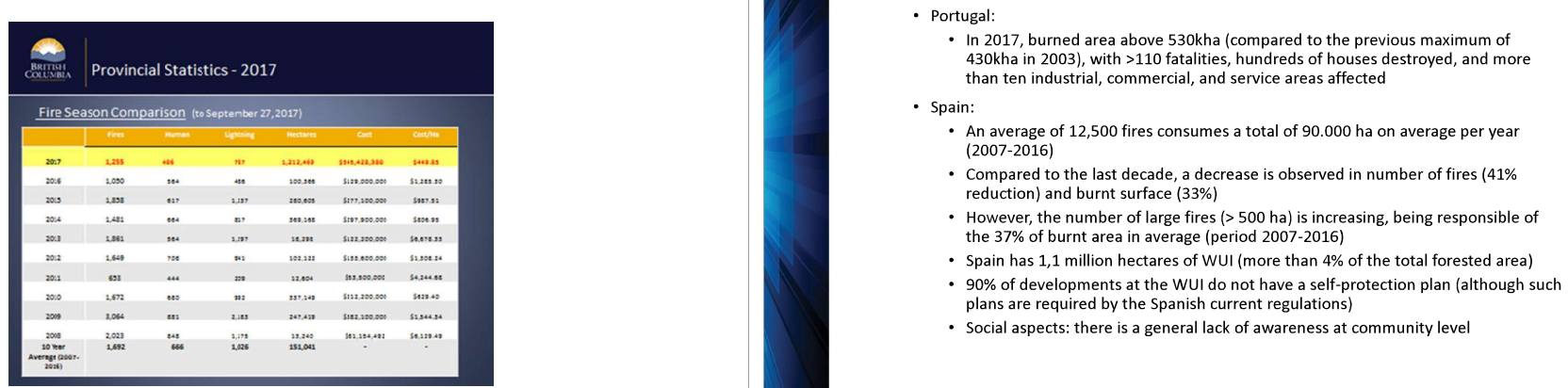

- Italy:

- Wildfires are a large issue in Italy

Wildfires are a large issue in Italy
$2016 / 2017$ showed significant increase

2016/2017 showed significant increase

Over 220,000 interventions (including all means) in 2016/2017 (vs 130,000 in 2015/2016)
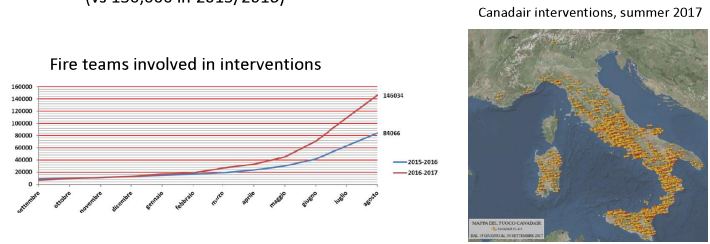

All data from AIB, Antincendi boschivi

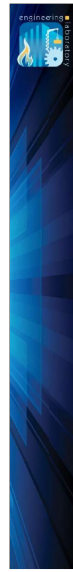

Wildfiresi

- High risk of more frequent large fires due to the projected drier summer in the

future, especially in Southern Sweden
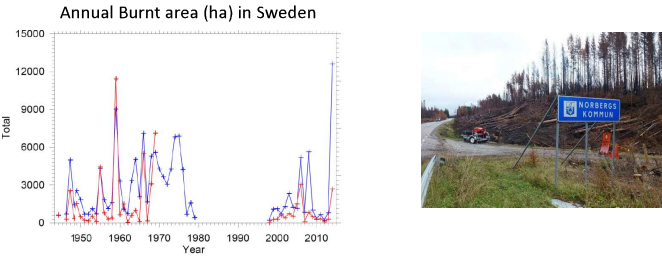

Västmanland fire in 2014 was the largest wildfire in recent decades in Sweden [area of 138 $\mathrm{km}^{2}, 70$ properties damaged/destroyed, 1 death, evacuation of $1000+$ people, total estimated cost of 1 billion SEK

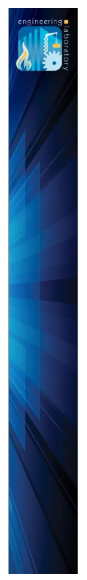

Large Outdoor Fires and the Built Environment - France:

- In metropolitan France, there are 16 million hectares (ha) of forest, i.e. 30 per cent

of French territory

- The area of combustible zones increased by 20 per cent between 1975 and 2007 as

- Woodlands in southern France are potentially highly combustible because of the

- 6,000 French municipalities are classed as "at risk from wildfire", i.e. one

- ${ }_{\text {municipality out of six }}$

- Three-quarters of the French municipalities that have experienced fires are in the

- In 2008 , with 2,781 wildfires, France ranked $8^{\text {th }}$ amongst European countries most

- Each year, on average, there are
burned in metropolitan France

- The number of fires is tending to stagnate, while the areas burned are reducing as

(a)

- Less than 2 per cent of fires spread over an area greater than 100 ha

- 90 per cent human in origin for those fires for which the cause is known fires

generally have harmful effects on ecosystems and are a hazard for structures within

or close to the risk area

- The regions at risk from wildfire are expected to extend significantly towards the
regions of northern France by 2040 as a result of the climate change predicted by
climatologists

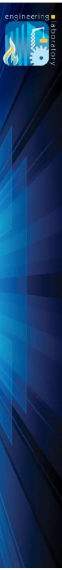

Large Outdoor Fires and the Built Environment

Itoigawa City Fire (May 19, 2017)

Largest urban fire in Japan since 1976 (not caused by earthquake)
飛び火した建物の位置·構造 (推定)

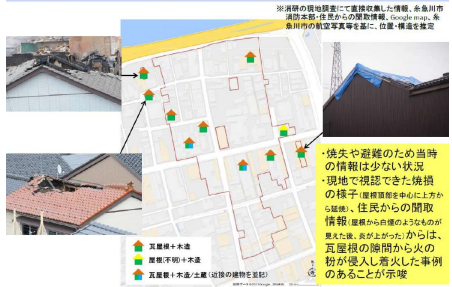

Importance of understanding firebrand exposure

147 structures were damaged by fire with 120 of 147 destroyed 

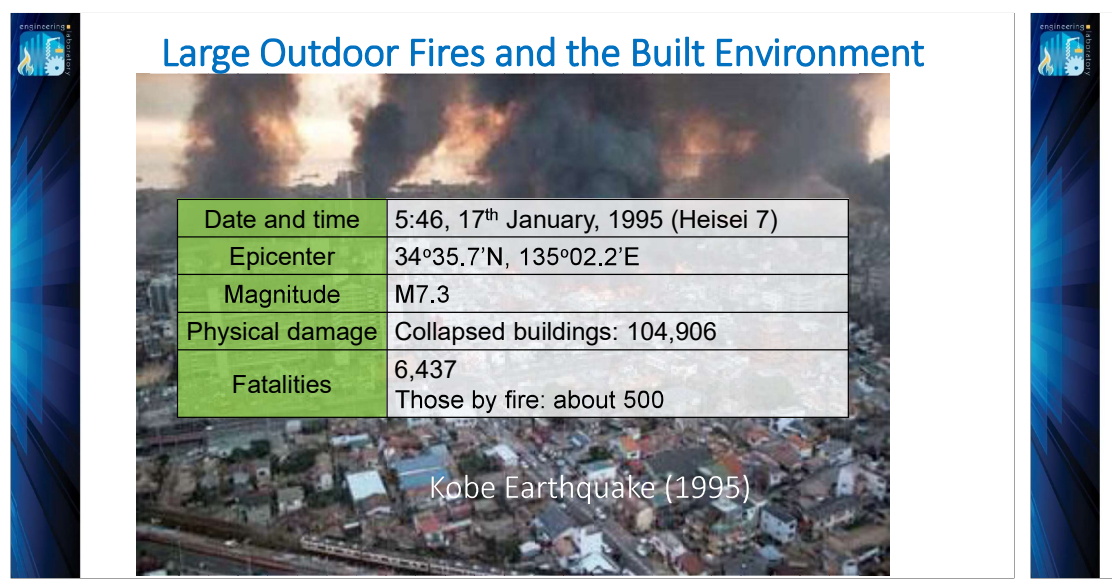

Large Outdoor Fires and the Built Environment Damage by Fire - Kobe Earthquake

\begin{tabular}{|r|r|r|r|r|}
\hline \multicolumn{5}{|c|}{ Number of ignitions } \\
\hline building : & 'vehicle & others & A total & \\
\hline 269 件 & 9 件 & 15 件 & $\underline{293}$ 件 & $\mathbf{8 3 5 , 8 5 8} \mathrm{m}^{3}$ \\
\hline
\end{tabular}

\begin{tabular}{|c|c|c|c|c|c|}
\hline \multirow{4}{*}{$\begin{array}{c}\text { 用途等 } \\
\text { 阵損区分 } \\
\begin{array}{c}\text { Totally } \\
\text { burnt }\end{array}\end{array}$} & \multirow{3}{*}{$\begin{array}{c}\text { Hyogo } \\
\text { Prefecture }\end{array}$} & \multicolumn{3}{|c|}{ Other prefectures } & \multirow{3}{*}{ total } \\
\hline & & \multirow{2}{*}{ 家 } & \multirow{2}{*}{ 非 1} & \multirow{2}{*}{$\begin{array}{c}\text { 家 } \\
\text { 三の他 }\end{array}$} & \\
\hline & & & & & \\
\hline & 7,035 棟 & 1 棟 & $\underline{\underline{0 \text { 暒 }}}$ & 柴 & 7. 036 棟 \\
\hline 樴 & 89 楝 & 5 棟 & 0 棟 & 2 棟 & 96 棵 \\
\hline 部分烧 & 313 棟 & 8 棟 & $\underline{2 \text { 棟 }}$ & 10 棟 & 333 性 \\
\hline$\$$ & 97 裸 & 6 棟 & 1 棟 & 5 梀 & 109 倲 \\
\hline 計 & 7,534 棟 & 20 梀 & 3 棟 & 17 梀 & 7,574 性 \\
\hline
\end{tabular}

※消防庁確定報

\section{Large Outdoor Fires and the Built Environment}

Ignition Points in Kobe

Belt of severe shaking

(JMA seismic scale of 7)

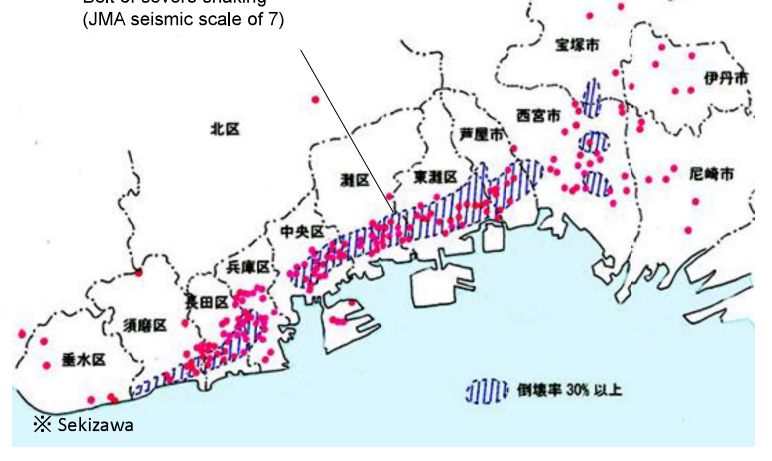

- Over the past several decades, fire safety science research has spent a great deal of effort to understand fire dynamics within buildings

- Research into large outdoor fires, and how to potentially mitigate the loss of structures in such fires, lags behind other areas of fire safety science research

- Fire spread in large outdoor fires is very complex, involving the

interaction of topography, weather, vegetation, and structures

- At the same time, common characteristics between fire spread in WUI fires and urban fires have not been fully exploited

- Once a wildland fire reaches a community and ignites structures,

structure-structure fire spread can occur under similar mechanisms as in urban fire spread

Large outdoor fires present a risk to the built environment

- Wildfires that spread into communities, referred to as Wildland-Urban Interface (WUI) fires

- WUI fires are a growing problem in fire safety science

- Another example are large urban fires, including those that have occurred after earthquakes

- May involve multi-risk emergencies: forest fire, urban fire, toxic smoke dispersion, industrial disasters due to cascade effects (e.g. hydrocarbon fires and explosions)

- Complexity increased due to the fire effects on critical infrastructure: road networks, electrical facilities, power lines and systems

- Our task: Propose global standardization needs roadmap for this topic to ISO TC92 
- Recent ASTM workshop looked at WUI codes and standards issues

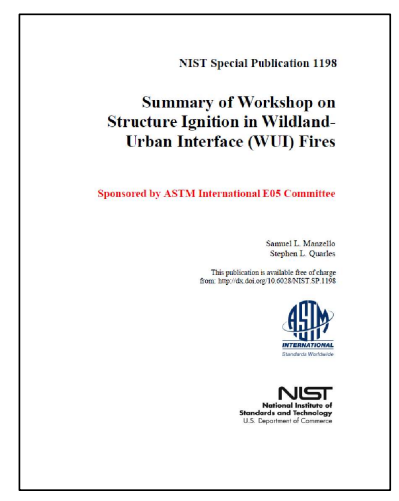

- Finding: current WUI codes/standards not adequat
Recent ASTM workshop looked at WUI codes and standards issues

Special Issue Published March, 2017 Fire Technology

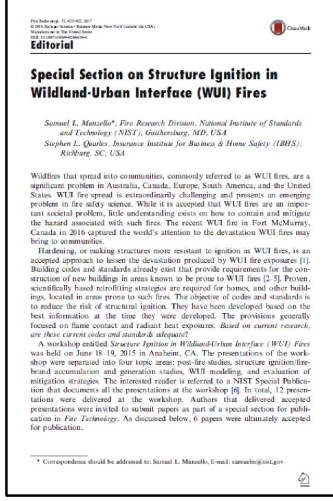

\section{Large Outdoor Fires and the Built Environment}

\author{
Key thoughts
}

As this problem encompasses so many areas, why not develop entire new structure for ISO TC92 to properly address it?

ISO TC92 SC5: Large Outdoor Fires and the Built Environment

WG1: More Ignition Resistant Communities

Develop representative standard test methods indicative of the exposures

WG2: Evacuation, Emergency Management

Develop effective
outdoor fires

WG3: Large Outdoor Firefighting

Develop global overview of various tactics that are used, as well as the various personal protective equipment (PPE)

WG4: Environmental Issues

Environmental issues related to both suppressing large outdoor fires, as well the exposure to products of combustion from these fires

The Following Slides Have Specific Suggestions

\section{Large Outdoor Fires and the Built Environment} Workshop - Delft 2018

Global Overview of Current Large Outdoor Firefighting Methods and

Global Overview of Current Large Outdoor Fire Standards

- WUI fire standards

- Urban fire standards - methods to mitigate structure to structure spread

- Once WUI fire reaches communities - urban fire problem

- Invite several key speakers

- Document presentations in joint ISO/NIST Special Publication

- Publish Special Issue in one of the main fire journals

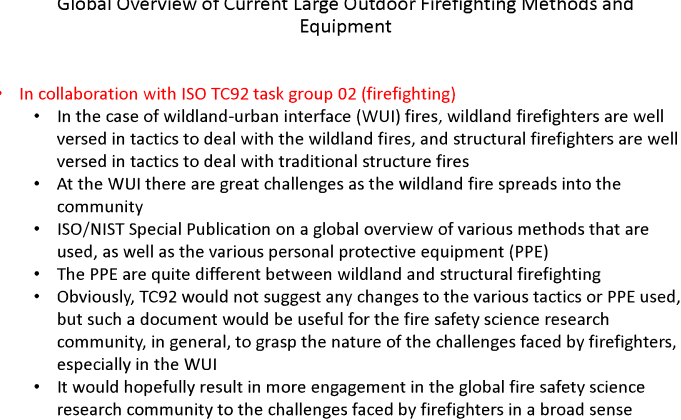

- It would hopefully result in more engagement in the global fire safety science research community to the challenges faced by firefighters in a broad sense 
Large Outdoor Fires and the Built Environment

Future Suggestions for SC5: WG1 to WG4

\author{
If no SC5, work items as a Working Group \\ under ISO TC92?
}

Large Outdoor Fires and the Built Environment

- Standardized real scale combustibility tests such as burning rate, flame geometry of residential vegetation and artificial fuels

- Flammability of ornamental fuels has been studied analytically in laboratories giving comparative data among species but there is poor information about real burning characteristics

- Structural fuels impact and interaction at WUI is even less

understood than natural fuels

- Standardized real scale vulnerability tests of building systems

- Tested at real scale under a standardized protocol

- Harmonization on firebrand testing/assessment

- Ignitions from isolated 'pockets' of fire - spewing, flaming liquid from tanks

- WUI standard definition and classification

- There are several definitions and classifications around the world that should be gathered, compared, and adapted to the different realities according to an harmonized system

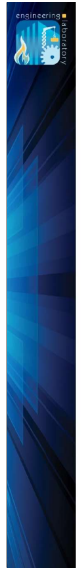

\section{Large Outdoor Fires and the Built Environment}

Roadmap for developments in risk modelling

Other modelling efforts:

Risk Indexes for WUI developments

- Indexes which might help to discriminate high/low risk WUI developments, according to urban planning (population type and density, vulnerable elements, etc.), to the ease/difficulty of fire fighting deployment (accessibility, fire hydrants availability, etc.) to the expected wildfire intensity in the surroundings (driven by characteristic slope, wind, and fuels)

- Risk indexes for WUI homes/lots (micro-scale)

- Indexes or protocols which might help to discriminate defensible/indefensible lots or homes

- Indexes and protocols which might help to identify inherently safe homes/spaces to be used as shelters 


\section{USDA}

Permanent Working Group Underway

The executive committee of the IAFSS has formally approved Large Outdoor Fires and the Built Environment as permanent working group

Samuel Manzello (NIST, EL), Sara McAllister (USFS, USA), and Sayaka Suzuki (NRIFD, Japan) are co-leaders

The working group consists of three subgroups focused: gnition Resistant Communities (IRC)

Emergency Management and Evacuation (EME) Large Outdoor Firefighting (LOFF)

The overall objectives are to bring full depth of knowledge of the IAFSS community to work on these priority topics

Poster at European IAFSS Kick-off meeting at Asia-Oceania IAFSS

THE INTERNATIONAL ASSOCIATION FOR FIRE SAFETY SCIENCE

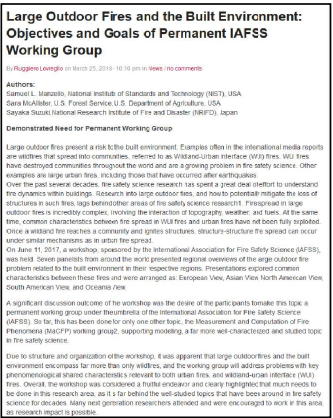

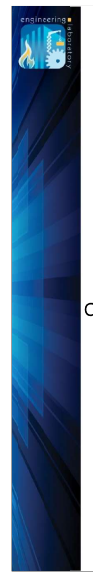

USDA

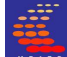

Permanent Working Group Underway

Workshop Summary paper published in Fire Safety Journal

Overview of the

large outdoor fire risk to the built environment from each region presented

Critical research needs for this problem in the context of fire safety science are provided

Seeks to develop foundation for an international research needs roadmap to reduce the risk of large outdoor fires to the built environment

THE INTERNATIONAL ASSOCIATION FOR FIRE SAFETY SCIENCE
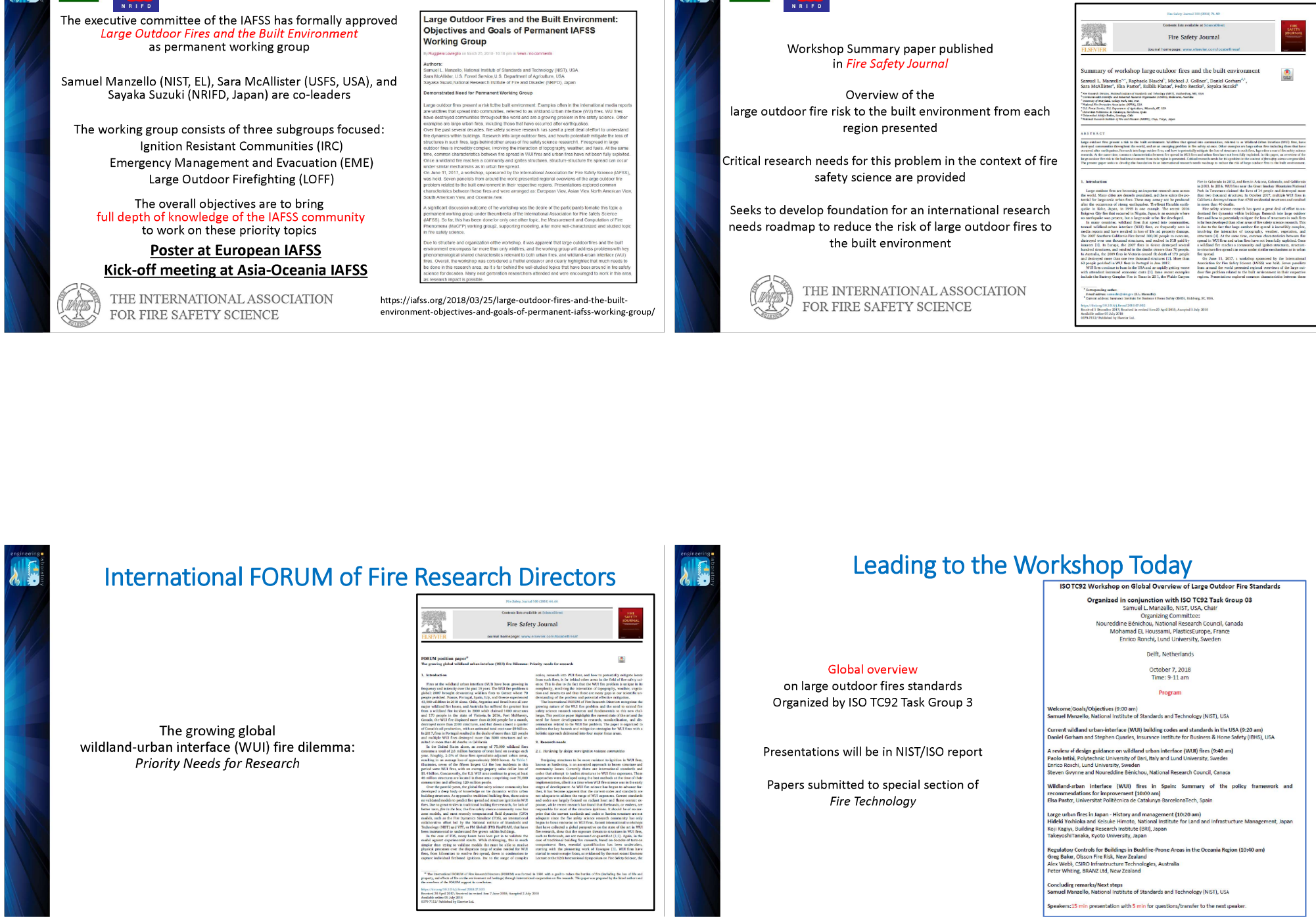

\section{International FORUM of Fire Research Directors}

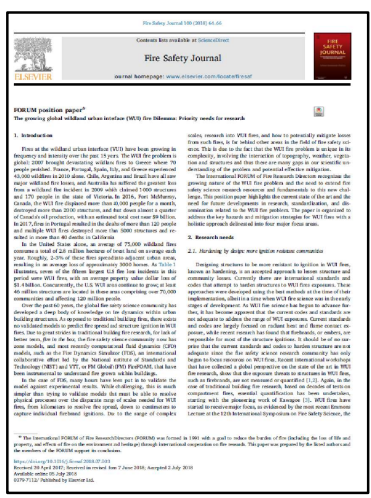

The growing global wildland-urban interface (WUI) fire dilemma: Priority Needs for Research

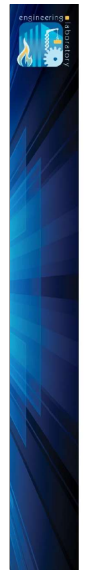

\section{Leading to the Workshop Today}

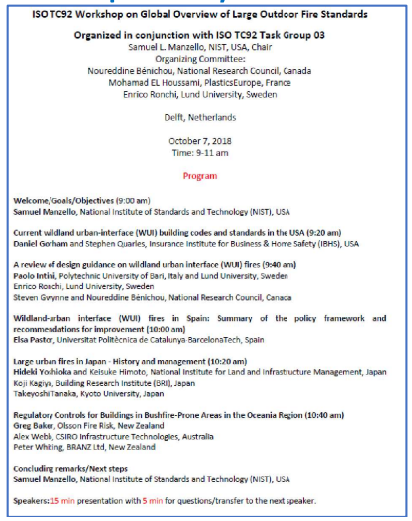

Global overview
on large outdoor fires standards Organized by ISO TC92 Task Group 3

Presentations will be in NIST/ISO report

Papers submitted to special section of Fire Technology 


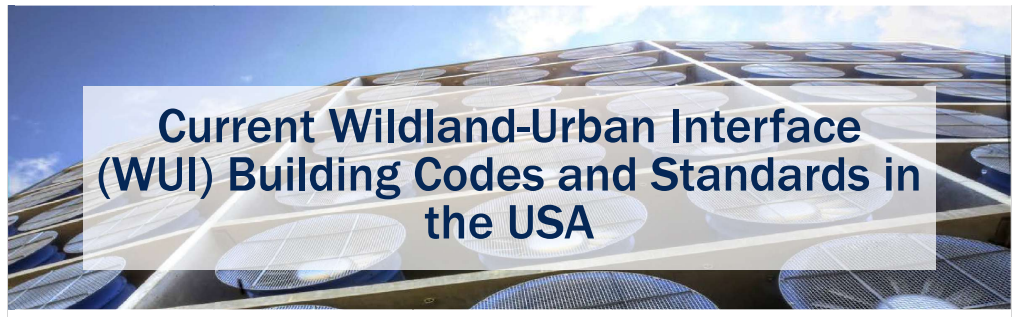

ISO TC92 Workshop on Global Overview of Large Outdoor Fire Standards

Sunday October 7, 2018

Daniel Gorham and Stephen Quarles

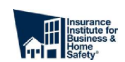

\section{Wildland-Urban Interface/Intermix}
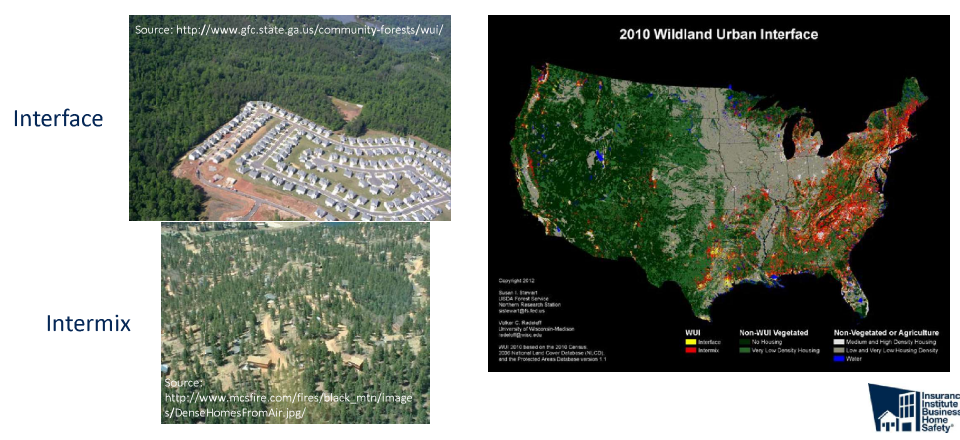

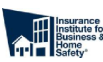

\section{Building Ignition Mechanisms}

- Firebrands

o Direct

- Indirect

- Radiation

- Direct Flame Contact

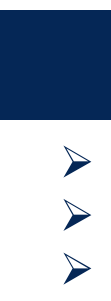

Defining the WUI

Building ignition mechanisms

Building codes \& standards

$>$ Standard test methods

$>$ Opportunities for improvements

\section{Outline}


Ignition-Resistant Classification (IRC) Requirements

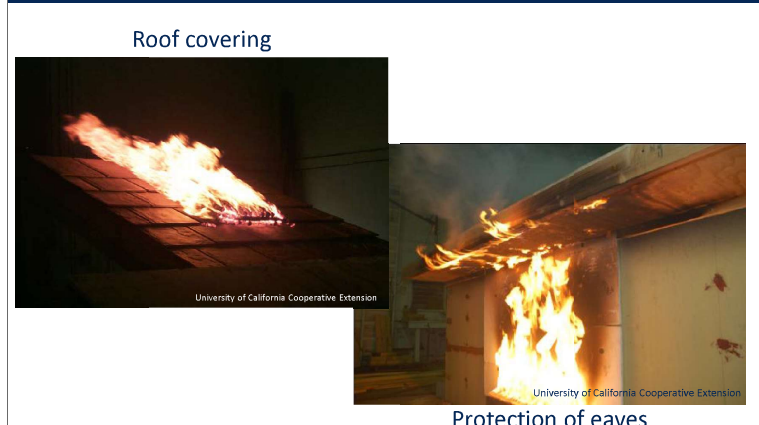

Exterior wall

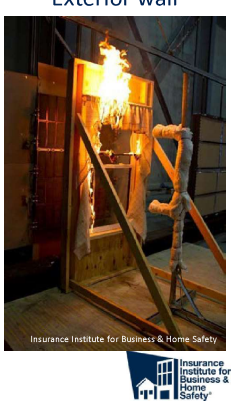

\section{Defensible Space}

Noncombustible, 0-5 ft

Zone 1, 5-30 ft

Zone 2, 30-100 ft

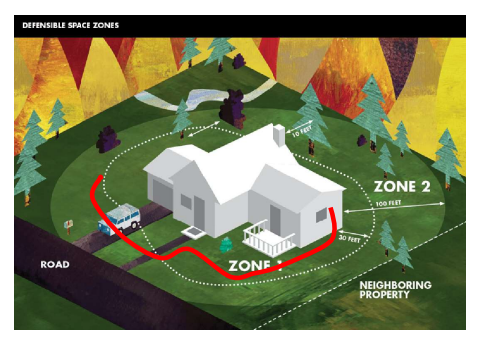

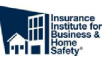

\section{A Coupled Approach}

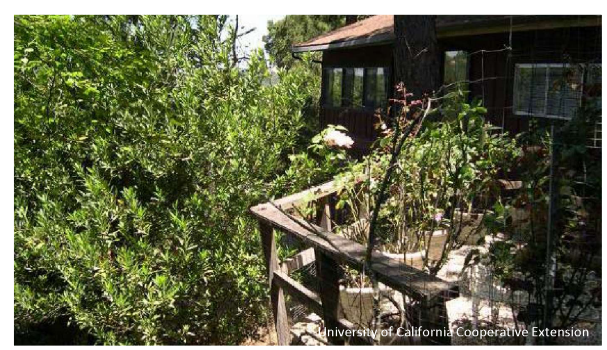

Vegetation management \&

Building materials

\section{Evaluation of 5-ft distance}
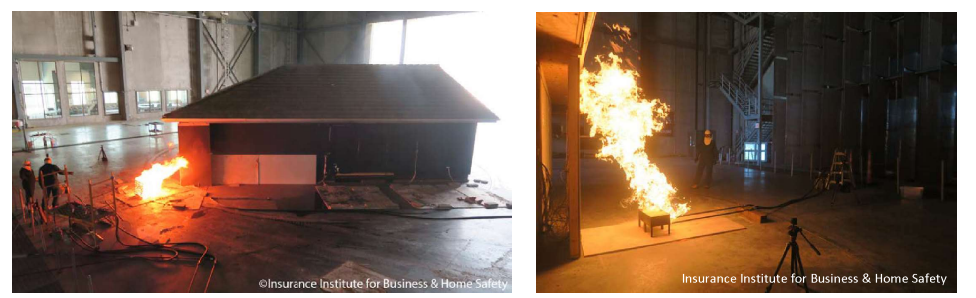

\section{Noncombustible Zone}
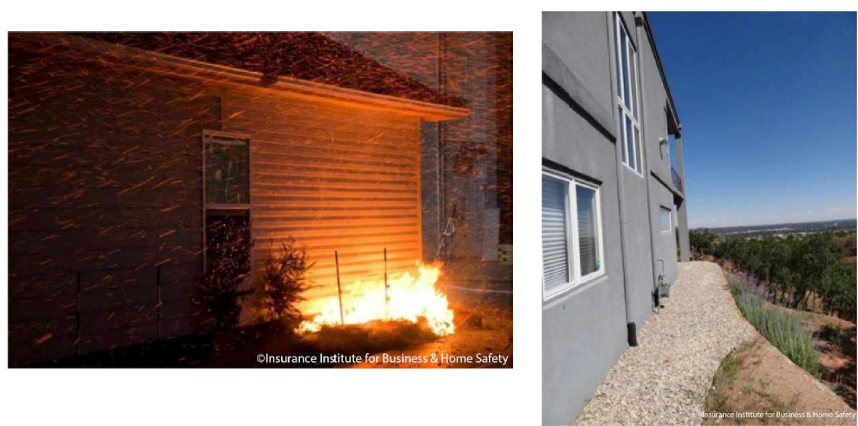

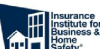

\section{Standard Test Methods for Combustible Decking}

ASTM E-2726 Standard Test Method for Evaluating the Fire-Test-Response of Deck Structures to Burning Brands

ASTM E-2632* Standard Test Method for Evaluating the Under-Deck Fire Test Response of Deck Materials

ASTM E84 Standard Test Method for Surface Burning Characteristics of Building Materials

Mandatory in California for walking surface 

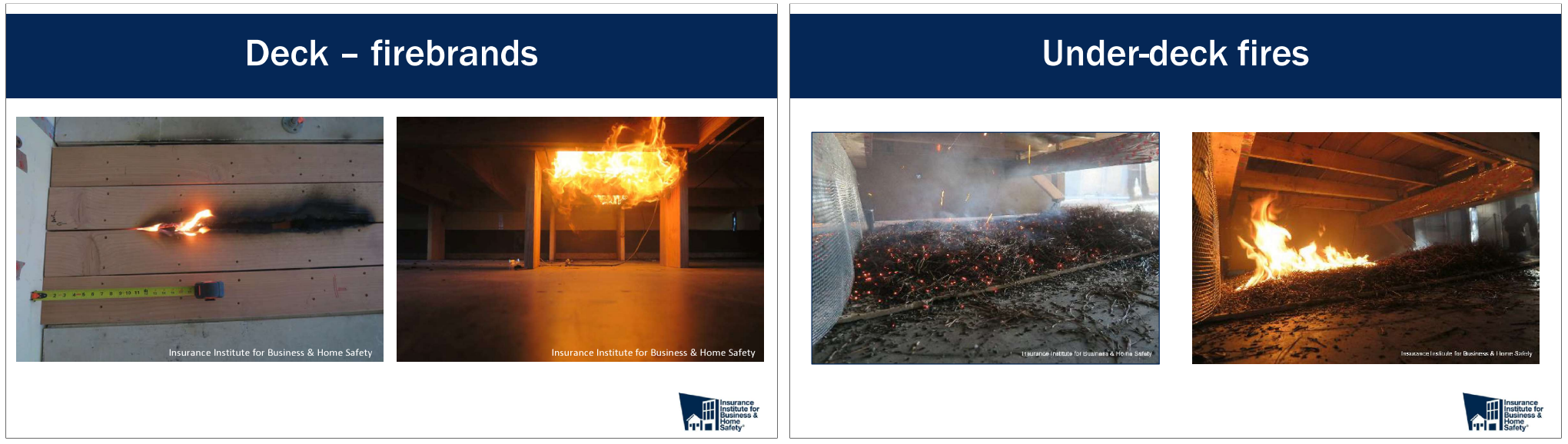

\section{Summary}

WUI definition should include building/population density and home-to-home ignition risk

- Local building codes referencing/including WUI requirements \& reference standards

Opportunities for improvement:

$>$ Implement/require noncombustible zone

$>$ Firebrand and under-fire exposure to decks

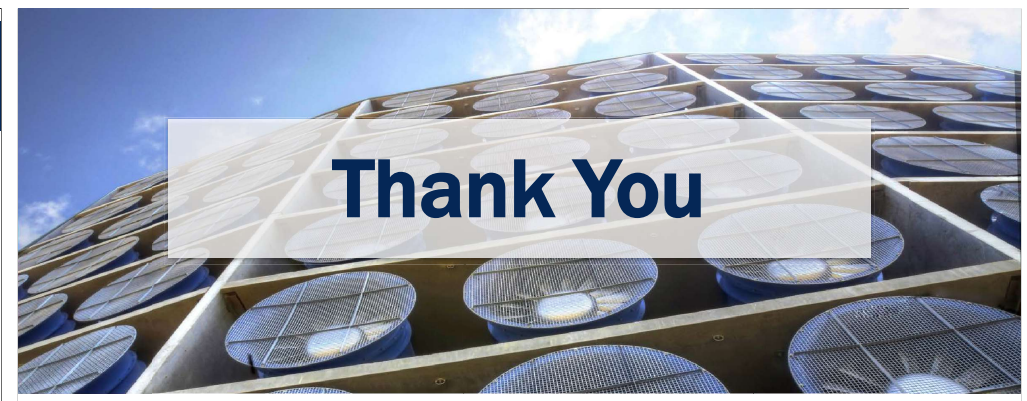

\section{Questions?}


ISO TC92 Workshop on Global Overview of Large Outdoor Fire Standards Delft - 2018.10.07

\section{A review of design guidance on wildland urban interface fires}

Paolo Intini, Ph.D.

Post-Doctoral Research Fellow

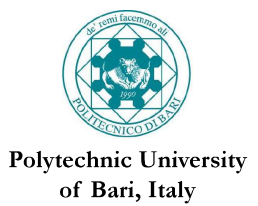

Review of design guidance on Wildland Urban Interface fires

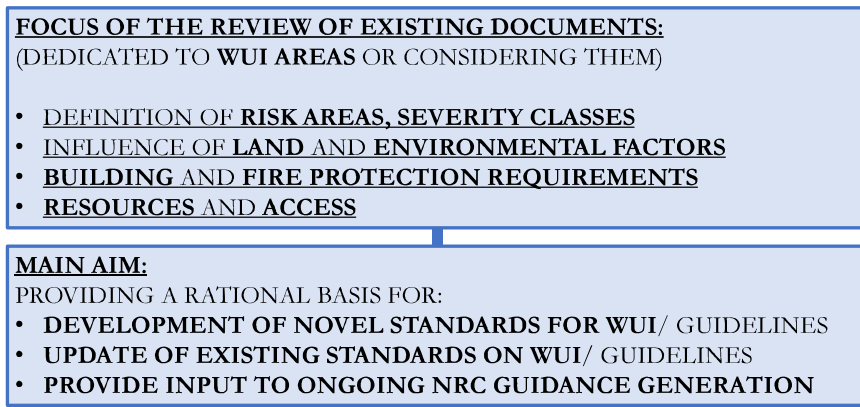

ISO TC92 Workshop: «Global Overview of Large Outdoor Fire Standards» - Delft - 2018.10.07 Paolo Intini

\section{DOCUMENTS REVIEWED}

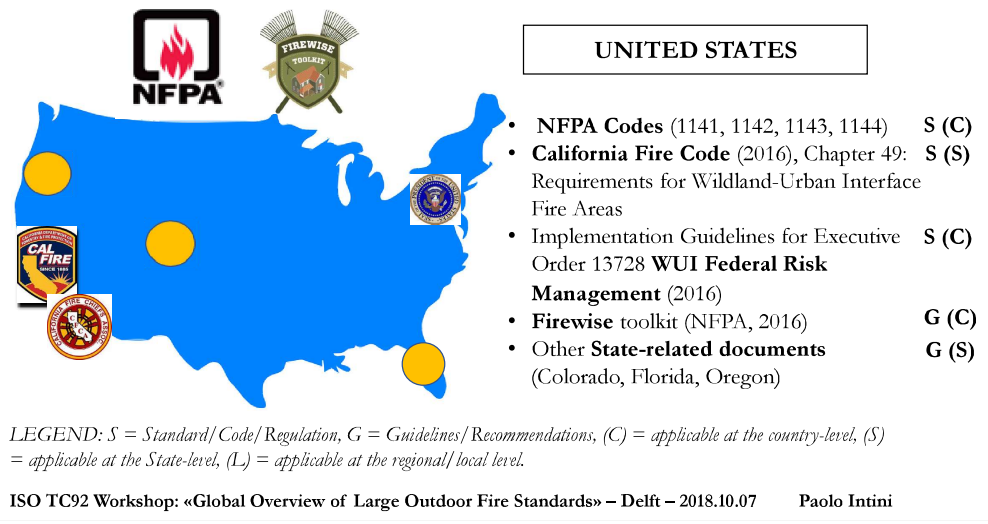

Review of design guidance on Wildland Urban Interface fires

OVERVIEW:

1. DOCUMENTS REVIEWED

2. METHODS USED FOR THE REVIEW

3. PRESENTATION OF RESULTS

4. CONCLUSIONS

Based on the report by

Paolo Intini

Polytechnic University of Bari

Lund University

Enrico Ronchi

Lund University

Steven Gwynn

NRC Canada

Noureddine Bénichou

NRC Canada

Project: "Design Guidance on wildland urban interface (WUI) fires"

Sponsor: NRC Canad

ISO TC92 Workshop: «Global Overview of Large Outdoor Fire Standards» - Delft - 2018.10.07 Paolo Intini

\section{DOCUMENTS REVIEWED}

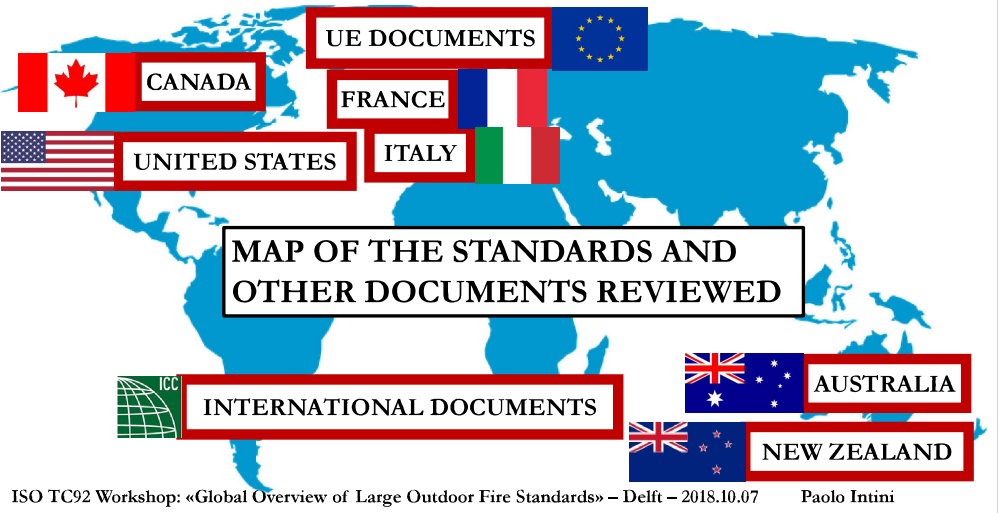

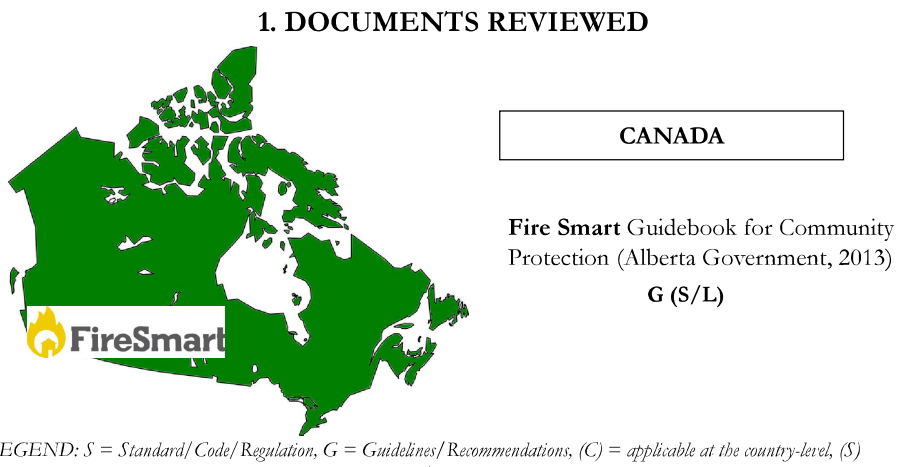

$=$ applicable at the State-level, $(L)=$ applicable at the regional/ local level.

ISO TC92 Workshop: «Global Overview of Large Outdoor Fire Standards» - Delft - 2018.10.07

Paolo Intini 


\section{DOCUMENTS REVIEWED}

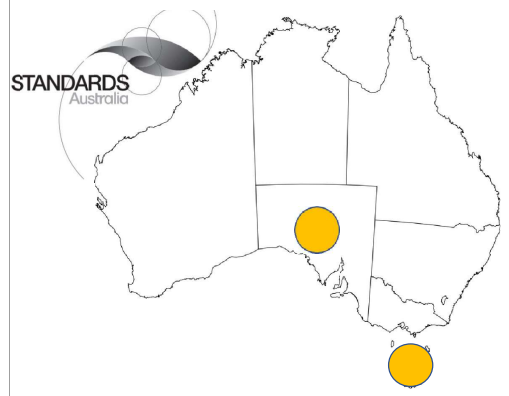

- Construction of buildings in bushfire-prone areas (Australian Standard, 2009)

- Guidelines of the States of South Australia (Government of South Australia, 2017) and Tasmania (Government of Tasmania, 2005)

LEGEND: $S=$ Standard $/$ Code $/$ Regulation, $G=$ Guidelines $/$ Recommendations, $(C)=$ applicable at the country-level, $(S)$ $=$ applicable at the State-level, $(L)=$ applicable at the regional/ local level

ISO TC92 Workshop: «Global Overview of Large Outdoor Fire Standards» - Delft - 2018.10.07 Paolo Intini

\section{DOCUMENTS REVIEWED}

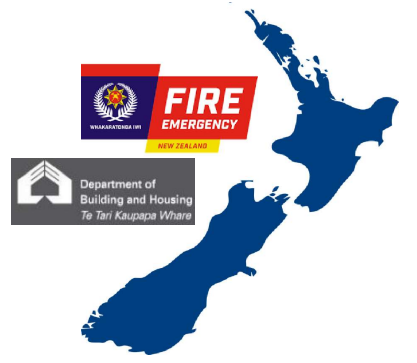

NEW ZEALAND

- Fire Emergency New Zealand Act (Fire and Emergency New Zealand, 2017)

- New Zealand Building Code, Extract: Clauses C1-C6, A3 (2012)

- Guidelines from Fire and Emergency New Zealand
S (C)

$\mathrm{S}(\mathrm{C})$

LEGEND: $S=S$ tandard $/$ Code $/$ Regulation, $G=$ Guidelines $/$ Recommendations, $(C)=$ applicable at the country-level, $(S)$ $=$ applicable at the State-level, $(L)=$ applicable at the regionall local level.

ISO TC92 Workshop: «Global Overview of Large Outdoor Fire Standards» - Delft - 2018.10.07 Paolo Intini

\section{DOCUMENTS REVIEWED}

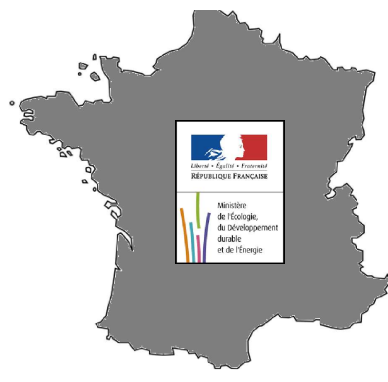

LGEND: $S=S$ tandard $/$ Code $/$ Regulation $G=$ Guidelines $/$ Recommendations, $(C)=$ applicable at the country-level, $(S)$ $=$ applicable at the State-level, $(L)=$ applicable at the regional/ local level.

ISO TC92 Workshop: «Global Overview of Large Outdoor Fire Standards» - Delft - 2018.10.07 Paolo Intini
$\mathrm{S}(\mathrm{C})$

- Risques d'incendies de foret. Guide G(C) méthodologique (Risk for forest fires. Methodological guidance) (2002)

- Guidelines and Plan to Prevent G(L) Predictable Fires (Département de la Haute-Corse, 2013)

\section{DOCUMENTS REVIEWED}

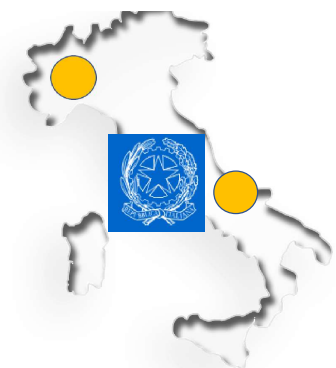

ITALY

- "Legge quadro in materia di incendi S(C) boschivi" (Framework law concerning wildfires) (2000)

- Recommendations for fires and interface $\mathrm{S}(\mathrm{C})$ fires (Presidency of Ministry Council, 2017).

- Regional Guidelines (Molise, Piemonte)

LEGEND: $S=$ Standard $/$ Code $/$ Regulation, $G=$ Guidelines $/$ Recommendations, $(C)=$ applicable at the country-level, $(S)$ $=$ applicable at the State-level, $(L)=$ applicable at the regional l locial level.

ISO TC92 Workshop: «Global Overview of Large Outdoor Fire Standards» - Delft - 2018.10.07 Paolo Intini

\section{DOCUMENTS REVIEWED}
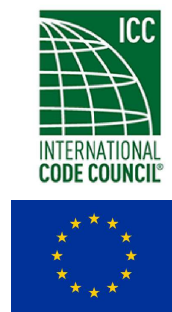

- Council Regulation (EEC) No 2158/92 of 23 July 1992 (European Commission, 1992);

- EC 2152/2003 (Forest Focus) (European Council, 2003). S (I)

International Wildland-Urban Interface Code (International Code Council, 2015).

\section{METHODS USED FOR THE REVIEW}

CONSISTENT TEMPLATE FOR EACH STANDARD/MAIN DOCUMENT/GROUP OF SIMILAR GUIDELINES

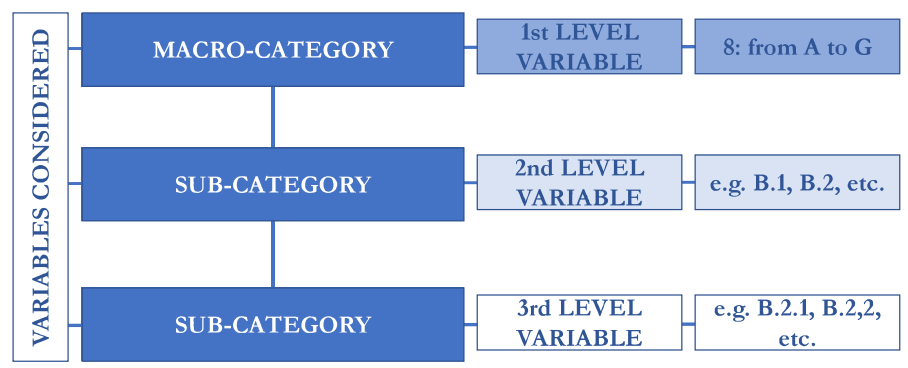

ISO TC92 Workshop: «Global Overview of Large Outdoor Fire Standards» - Delft - 2018.10.07 Paolo Intini 


\section{METHODS USED FOR THE REVIEW}

VARIABLES IN THE TEMPLATE

\section{MACRO-CATEGORY}

SUB-CATEGORY

SUB-CATEGORY

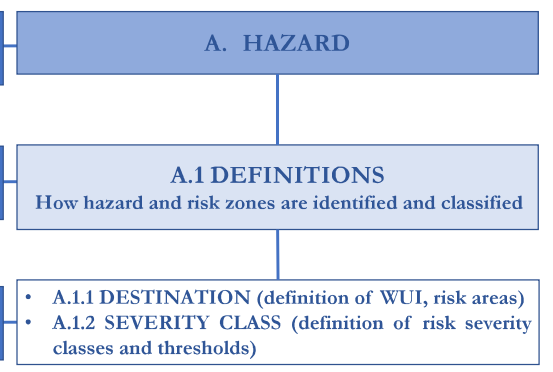

ISO TC92 Workshop: «Global Overview of Large Outdoor Fire Standards» - Delft - 2018.10.07 Paolo Intini

\section{METHODS USED FOR THE REVIEW}

VARIABLES IN THE TEMPLATE

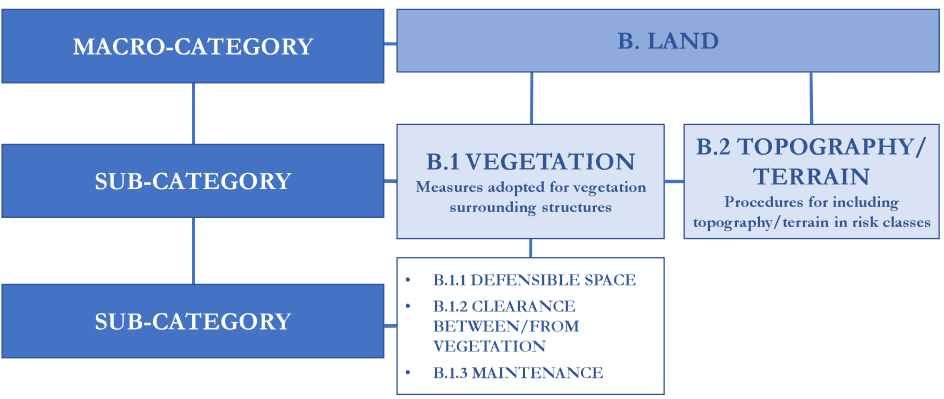

ISO TC92 Workshop: «Global Overview of Large Outdoor Fire Standards» - Delft - 2018.10.07 Paolo Intini

\section{METHODS USED FOR THE REVIEW}

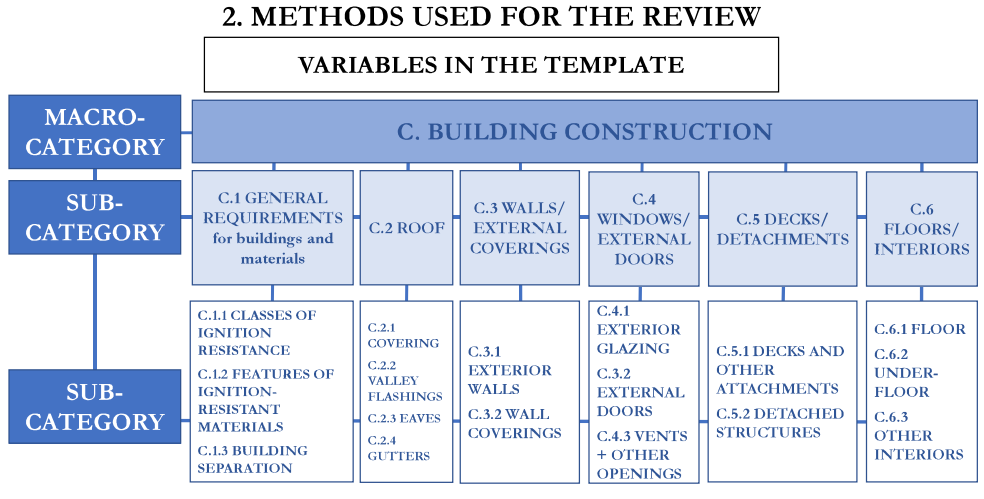

ISO TC92 Workshop: «Global Overview of Large Outdoor Fire Standards» - Delft - 2018.10.07 Paolo Intini

\section{METHODS USED FOR THE REVIEW}

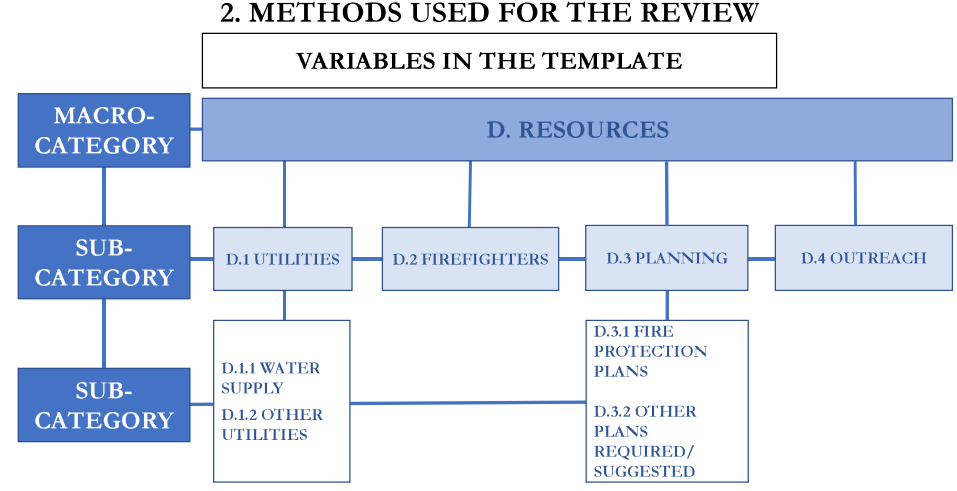

ISO TC92 Workshop: «Global Overview of Large Outdoor Fire Standards» - Delft - 2018.10.07 Paolo Intini

\section{METHODS USED FOR THE REVIEW}

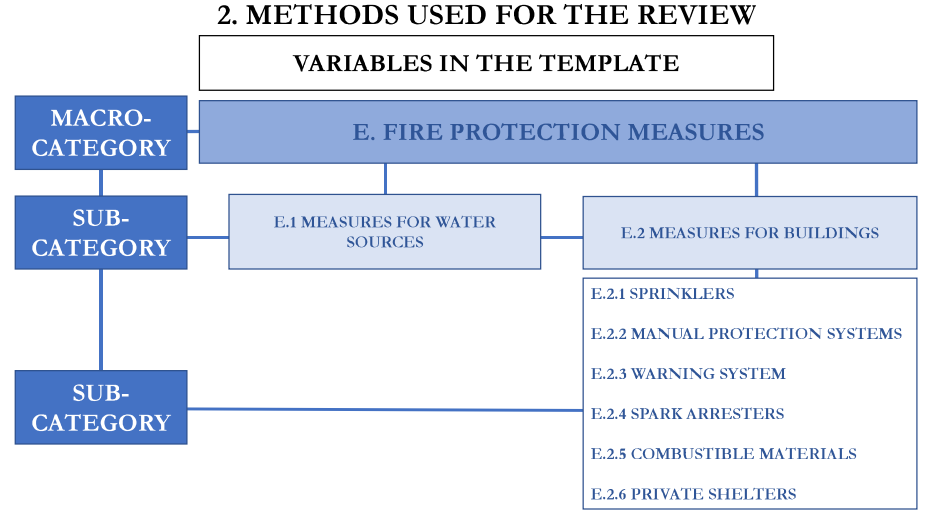

ISO TC92 Workshop: «Global Overview of Large Outdoor Fire Standards» - Delft - 2018.10.07 Paolo Intini

\section{METHODS USED FOR THE REVIEW}

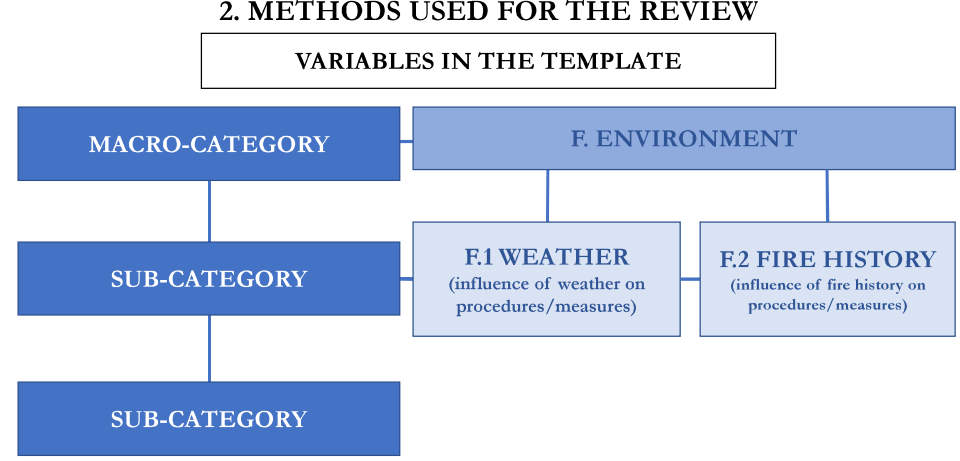

ISO TC92 Workshop: «Global Overview of Large Outdoor Fire Standards» - Delft - 2018.10.07 Paolo Intini 


\section{METHODS USED FOR THE REVIEW}

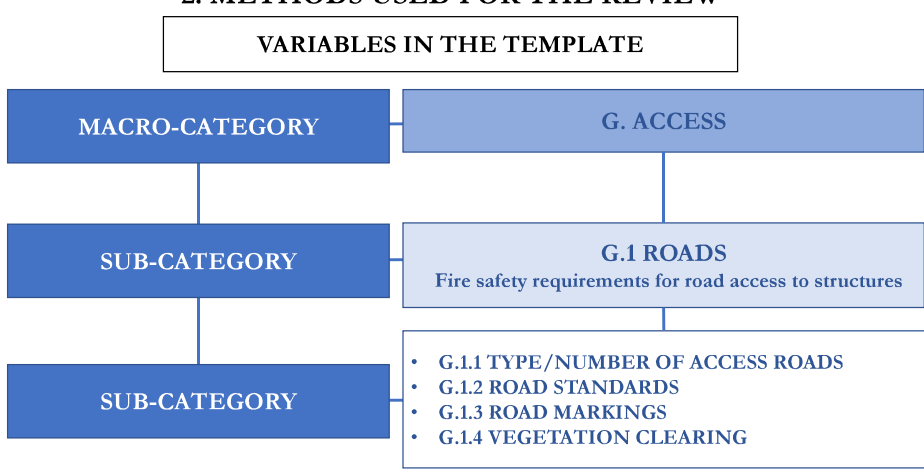

ISO TC92 Workshop: «Global Overview of Large Outdoor Fire Standards» - Delft - 2018.10.07 Paolo Intini

\section{PRESENTATION OF RESULTS}

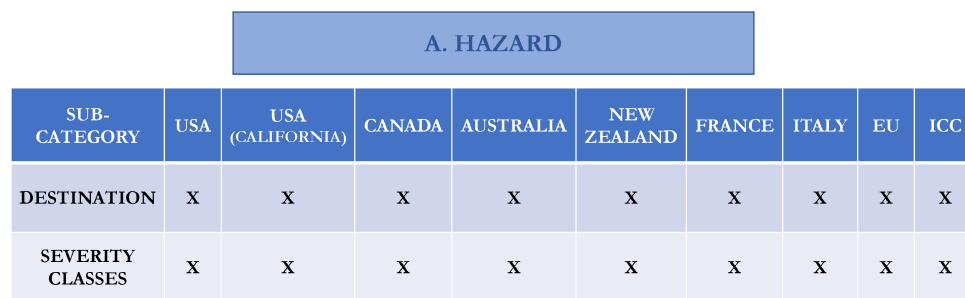

$\mathrm{X}=$ element present in the standards/guidelines reviewed, $\mathrm{x}=$ partially considered (e.g. in a qualitative way, or only some aspects)

COMMENTS

- Definitions of wildfire risk and hazard levels based in all documents (except NZ) on topography, vegetation and environment. - Different levels of refinement in the Methods for identifying and classifying severity in WUI areas (e.g. methods based on partial ratings or on fire history, such as EU standards).

ISO TC92 Workshop: «Global Overview of Large Outdoor Fire Standards» - Delft - 2018.10.07 Paolo Intini

\section{PRESENTATION OF RESULTS}

\section{B. LAND}

\begin{tabular}{|c|c|c|c|c|c|c|c|c|c|}
$\begin{array}{c}\text { SUB- } \\
\text { CATEGORY }\end{array}$ & USA & $\begin{array}{c}\text { USA } \\
\text { (CALIFORNA) }\end{array}$ & CANADA & AUSTRALIA & $\begin{array}{c}\text { NEW } \\
\text { ZEALAND }\end{array}$ & FRANCE & ITALY & EU & ICC \\
\hline VEGETATION & $\mathbf{x}$ & $\mathbf{x}$ & $\mathbf{x}$ & $\mathbf{x}$ & $\mathbf{x}$ & $\mathbf{x}$ & $\mathbf{x}$ & $\mathbf{x}$ \\
$\begin{array}{c}\text { TOPOGRAPHY } \\
\text { /TERRAIN }\end{array}$ & $\mathbf{x}$ & $\mathbf{x}$ & $\mathbf{x}$ & $\mathbf{x}$ & & $\mathbf{x}$ & $\mathbf{x}$ & $\mathbf{x}$ \\
\hline
\end{tabular}

$\mathrm{X}=$ element present in the standards/guidelines reviewed, $\mathrm{x}=$ partially considered (e.g. in a qualitative way, or only some aspects) COMMENTS:

- Concept of defensible space present in all documents reviewed (except EU standards)

- Topographic and terrain factors generally affect definitions of risk areas, defensible space and position between houses and slopes.

ISO TC92 Workshop: «Global Overview of Large Outdoor Fire Standards» - Delft - 2018.10.07 Paolo Intini

\begin{tabular}{|c|c|c|c|c|c|c|c|c|c|}
\hline \multirow{2}{*}{\multicolumn{10}{|c|}{$\begin{array}{l}\text { 3. PRESENTATION OF RESULTS } \\
\text { C. BUILDING CONSTRUCTION }\end{array}$}} \\
\hline & & & & & & & & & \\
\hline SUB-CATEGORY & USA & \begin{tabular}{|c|} 
USA \\
(CALIFORNIA) \\
\end{tabular} & CANADA & AUSTRALIA & $\begin{array}{c}\text { NEW } \\
\text { ZEALAND } \\
\end{array}$ & FRANCE & ITALY & EU & ICC \\
\hline $\begin{array}{c}\text { GENERAL } \\
\text { REQUIREMENTS }\end{array}$ & $\mathbf{x}$ & $\mathrm{x}$ & & $\mathrm{x}$ & $\mathrm{x}$ & & $\mathrm{x}$ & & $\mathbf{x}$ \\
\hline $\begin{array}{l}\text { ROOF } \\
\begin{array}{l}\text { (covering, caves, gutters, valley } \\
\text { flashings) }\end{array}\end{array}$ & $\mathrm{x}$ & $\begin{array}{c}\mathbf{X} \\
\text { (no gutters, also } \\
\text { valley flashings) }\end{array}$ & $\mathrm{x}$ & $\begin{array}{c}\underset{\text { (also valley }}{\text { (flashings) }} \\
\mathbf{X}\end{array}$ & $\underset{\text { (no gutters) }}{\mathbf{X}}$ & $\mathrm{x}$ & $\underset{\substack{(n o \\
\text { gutters) }}}{\mathbf{X}}$ & $\underset{\substack{\text { (no } \\
\text { gutters) }}}{\mathbf{X}}$ & $\begin{array}{c}\mathbf{X} \\
\text { (also valley } \\
\text { flashings) }\end{array}$ \\
\hline $\begin{array}{l}\text { WALLS/EXTERNAL } \\
\text { COVERINGS }\end{array}$ & $\mathbf{x}$ & $\begin{array}{c}\mathbf{X} \\
\text { (also wall } \\
\text { coverings) }\end{array}$ & $\mathrm{x}$ & $\mathrm{x}$ & $\mathrm{x}$ & $\begin{array}{c}\mathbf{X} \\
\text { (also wall } \\
\text { coverings) }\end{array}$ & & & $\mathrm{x}$ \\
\hline $\begin{array}{l}\text { WINDOWS, DOORS, } \\
\text { VENTS }\end{array}$ & $\mathbf{x}$ & $\mathrm{x}$ & $\underset{\text { (no doors) }}{\mathbf{X}}$ & $\mathbf{x}$ & & $\begin{array}{c}\mathbf{x} \\
\text { (only vents) }\end{array}$ & & & $\mathrm{x}$ \\
\hline $\begin{array}{c}\text { DECKS/ } \\
\text { DETACHMENTS }\end{array}$ & $\begin{array}{c}\mathbf{X} \\
\text { (also } \\
\text { detach } \\
\text { ments) }\end{array}$ & $\mathrm{x}$ & $\mathrm{x}$ & $\underset{\substack{\text { (also detach- } \\
\text { ments) }}}{\mathbf{X}}$ & & $\begin{array}{c}\mathbf{x} \\
\text { (only } \\
\text { detach- } \\
\text { ments) }\end{array}$ & & & $\begin{array}{c}\mathbf{C} \\
\text { (also } \\
\text { detach- } \\
\text { ments) }\end{array}$ \\
\hline UNDER-FLOORS & $\mathbf{x}$ & $\mathrm{x}$ & $\mathrm{x}$ & $\underset{\substack{\text { (also } \\
\text { floors/interiors) }}}{\mathbf{X}}$ & $\begin{array}{c}x \\
\text { (only } \\
\text { floors/interiors) }\end{array}$ & & & & $\mathrm{x}$ \\
\hline \multicolumn{10}{|c|}{$=$ element present in the standards/guidelines reviewed, $x=$ partially considered (e.g. in a qualitative way, or only some aspects) } \\
\hline
\end{tabular}

\section{PRESENTATION OF RESULTS}

\begin{tabular}{|c|c|c|c|c|c|c|c|c|c|}
\hline SUB-CATEGORY & USA & $\begin{array}{c}\text { USA } \\
\text { (CAIIFORNIA) }\end{array}$ & CANADA & AUSTRALIA & $\begin{array}{c}\text { NEW } \\
\text { ZEALAND }\end{array}$ & FRANCE & ITALY & EU & ICC \\
\hline WATER SUPPLY & $\mathbf{x}$ & & $\mathrm{x}$ & $\mathbf{x}$ & $\begin{array}{l}x \\
\text { (also other utilities: } \\
\text { evacuation routes) }\end{array}$ & $\mathrm{x}$ & & & $\mathbf{x}$ \\
\hline FIREFIGHTERS & $x$ & & $x$ & & $x$ & $x$ & $x$ & & \\
\hline PLANNING & $\mathbf{x}$ & $\begin{array}{c}\mathrm{x} \\
\text { (no plans other } \\
\text { than fire } \\
\text { protection) }\end{array}$ & $\mathbf{x}$ & $\mathrm{x}$ & & $\begin{array}{c}\mathbf{x} \\
\text { (no plans } \\
\text { other than } \\
\quad \text { fire } \\
\text { protection) }\end{array}$ & $\mathrm{x}$ & $\mathrm{x}$ & $\mathrm{x}$ \\
\hline
\end{tabular}

OUTREACH Variable, depending on the type of document (i.e. standards, guidelines, local/statewide application) $\mathbf{X}=$ element present in the standards/guidelines reviewed, $\mathbf{x}=$ partially considered (c.g. in a qualitative way, or only some aspects) ISO TC92 Workshop: «Global Overview of Large Outdoor Fire Standards» - Delft - 2018.10.07 Paolo Intini
E. FIRE PROTECTION MEASURES

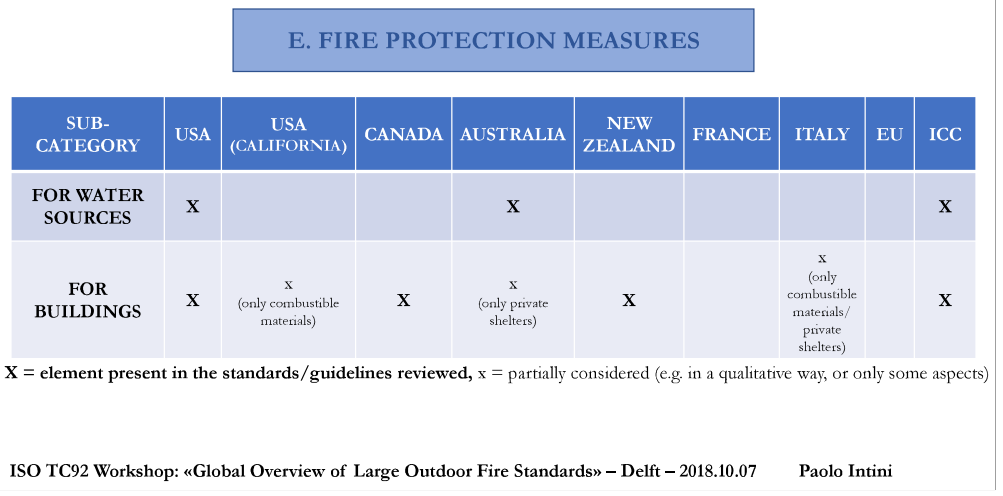




\section{PRESENTATION OF RESULTS}

\section{F. ENVIRONMENT}

\begin{tabular}{|c|c|c|c|c|c|c|c|c|c|}
\hline $\begin{array}{c}\text { SUB- } \\
\text { CATEGORY }\end{array}$ & USA & $\begin{array}{c}\text { USA } \\
\text { (CALIFORNIA) }\end{array}$ & CANADA & AUSTRALIA & $\begin{array}{c}\text { NEW } \\
\text { ZEALAND }\end{array}$ & FRANCE & ITALY & EU & ICC \\
\hline WEATHER & $\mathrm{x}$ & $\mathrm{x}$ & & $\mathbf{x}$ & & $\mathrm{x}$ & & & $\mathrm{x}$ \\
\hline FIRE HISTORY & $\mathrm{x}$ & & $\mathrm{x}$ & & & $\mathrm{x}$ & & $\mathrm{x}$ & $\mathbf{x}$ \\
\hline
\end{tabular}

ISO TC92 Workshop: «Global Overview of Large Outdoor Fire Standards» - Delft - 2018.10.07 Paolo Intini

\section{PRESENTATION OF RESULTS}

\section{G. ACCESS}

\begin{tabular}{|c|c|c|c|c|c|c|c|c|c|}
\hline $\begin{array}{c}\text { SUB- } \\
\text { CATEGORY }\end{array}$ & USA & $\begin{array}{c}\text { USA } \\
\text { (CALIFORNIA) }\end{array}$ & CANADA & AUSTRALIA & $\begin{array}{c}\text { NEW } \\
\text { ZEALAND }\end{array}$ & FRANCE & ITALY & EU & ICC \\
\hline $\begin{array}{c}\text { ROADS } \\
\begin{array}{c}\text { (type/number of } \\
\text { roads, standards, } \\
\text { markings, } \\
\text { vegetation) }\end{array}\end{array}$ & $\begin{array}{c}\mathbf{X} \\
\text { (also } \\
\text { makkings) }\end{array}$ & $\begin{array}{c}\text { (in the general } \\
\text { Fire Code) }\end{array}$ & $\mathbf{X}$ & $\mathbf{X}$ & $\begin{array}{c}\mathbf{X} \\
\text { (no }\end{array}$ & $\begin{array}{c}\text { typec number of } \\
\text { roads required, } \\
\text { also markings) }\end{array}$ & $\mathbf{X}$ & $\begin{array}{c}\mathbf{X} \\
\text { (no type/ } \\
\text { number } \\
\text { of roads } \\
\text { required) }\end{array}$ & $\begin{array}{c}\mathbf{X} \\
\text { (also } \\
\text { makkings) }\end{array}$ \\
\hline
\end{tabular}

$\mathrm{X}=$ element present in the standards/guidelines reviewed, $\mathrm{x}=$ partially considered (e.g. in a qualitative way, or only some aspects)

ISO TC92 Workshop: «Global Overview of Large Outdoor Fire Standards» - Delft - 2018.10.07 Paolo Intini

\section{CONCLUSIONS}

COMMON INDICATIONS/REQUIREMENTS:
- Each of the standards/guidelines reviewed provide definitions of risk areas (based on
topography, vegetation, environment) and severity classes for these areas;
- Most of the documents include some indications about the influence of land factors (i.e.
vegetation, terrain, topography), including definitions of defensible space.
- Most of the documents include some indications/requirements for buildings and access.

\section{DIFFERENCES/LACK OF INDICATIONS/REQUIREMENTS:}

- Requirements/indications about resources (especially water sources, firefighters) and about fire protection measures (for water sources) are scarce or lacking in several documents reviewed;

- The consideration of environmental factors (weather/fire history) lacks in several documents;

- Different methods were highlighted for defining severity classes and different aspects of building requirements are treated in different documents (some of them are more complete).

ISO TC92 Workshop: «Global Overview of Large Outdoor Fire Standards» - Delft - 2018.10.07 Paolo Intini
ISO TC92 Workshop on Global Overview of Large Outdoor Fire Standards Delft - 2018.10.07

\section{THANK YOU FOR THE ATTENTION}

\author{
Paolo Intini, Ph.D.
}

Post-Doctoral Research Fellow

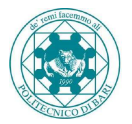

Polytechnic University of Bari, Italy 


\section{Wildland-urban interface fires in Spain}

\section{Summary of the policy framework and} recommendations for improvement

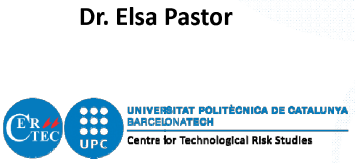

OUTLINE

WUI fires in Southern Europe

WUI fire management in Spain

Overview of the problem

- Spanish regulatory structure

- Overview of complience

Needs and Opportunities

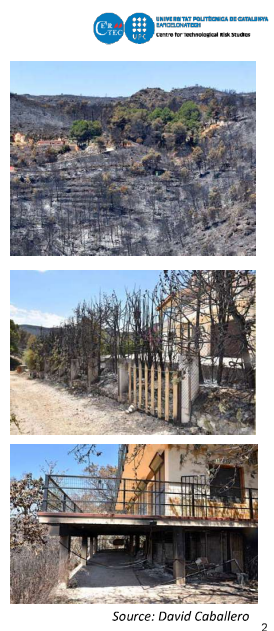

\section{WUI FIRES IN SOUTHERN EUROPE}

Europe has many areas in which forest fires seriously affect urban and rural communities

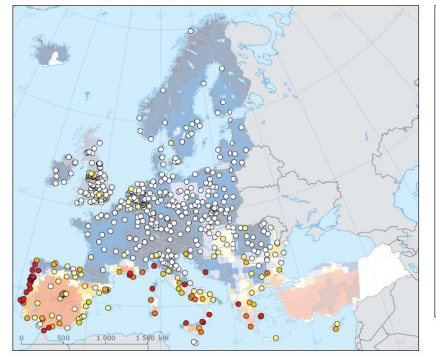

Populated areas (urban) at risk of forest fire in 2016.
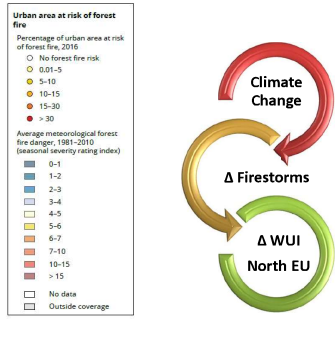

WUI FIRES IN SOUTHERN EUROPE

- Recent WUI fire events in Southern Europe

+ Madeira Island (Portugal, 2016)

+ Valencia (Spain, 2016)

r Rognac-Vitrolles (France, 2016)

4 Pedrógão Grande (Portugal, 2017)

- Ophelia winds wildfires (Spain \& Portugal, 2017)

Attica (Greece, 2018)

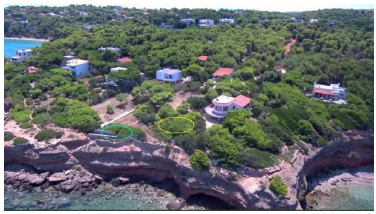

Before and ofter Mati fire (Yellow line is a zone of fire entrapementy

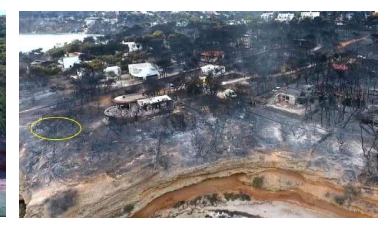

Source: David Caballer

\section{WUI FIRES IN SOUTHERN EUROPE}

EU does not hold a common overall strategy for fighting fires, but some efforts are slowly being devoted...

To create new polices covering WUI areas

- Harmonization through EU member states
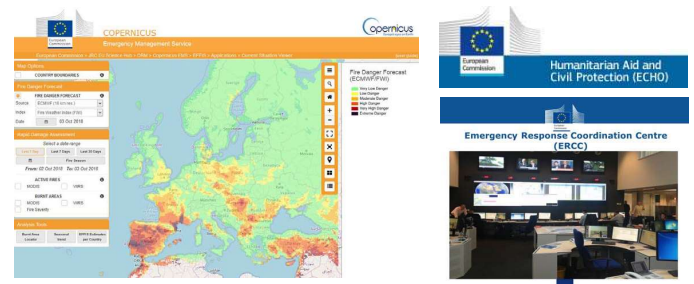

4 Current status of policies vary between EU countries

- Poor level of compliance (legal obligations fall ultimately on owners)
WUI FIRE MANAGEMENT IN SPAIN - Problem Overview

+ 12,500 forest fires per year on average during the last decade

1.1 million hectares of WUI (more than $4 \%$ of the total forested area)

- Massive influx of visitors at the WUI during fire season

WUI types

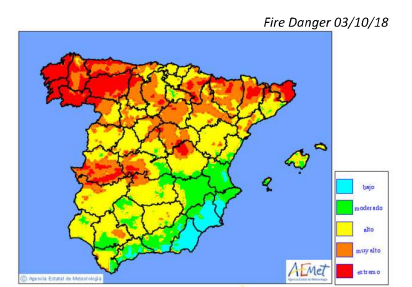

- Scattered houses in alegal/illegal urbanized areas

- Isolated houses in wildlands

Dense housing in touristic areas

Constructive materials: bricks and concrete

$\longrightarrow$ Home losses due to openings 
WUI FIRE MANAGEMENT IN SPAIN - Legal Framework

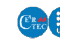

- Subsidiarity Principle - Autonomic Regions responsible of fire management at WUI LEVELS
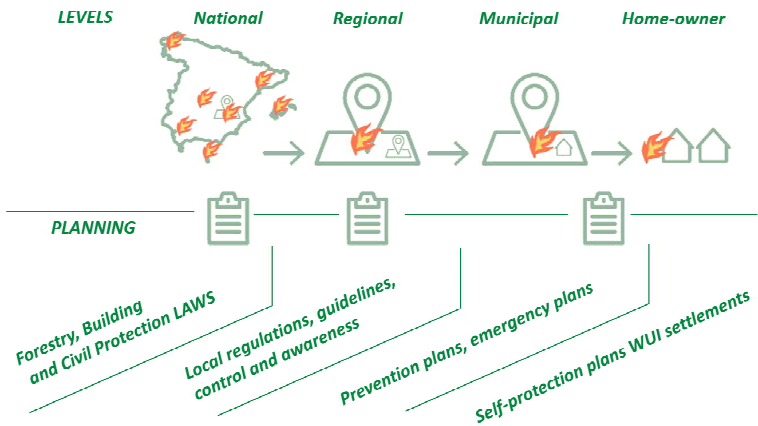

Adapted from Dalmau-Rovira, 2010
WUI FIRE MANAGEMENT IN SPAIN - Legal Framework

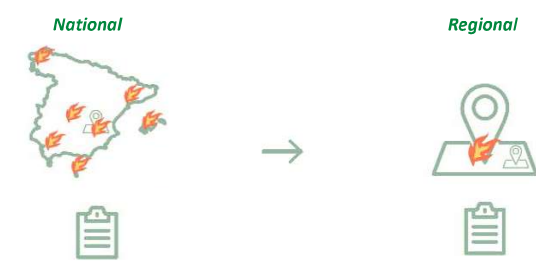

Basic Guideline of Civil Protection in Forest
Fires (RD 893/2013)
- Forestry Law (43/2003)

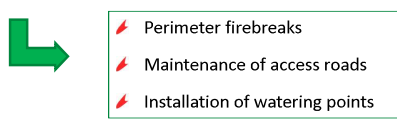

WUI FIRE MANAGEMENT IN SPAIN - Legal Framework

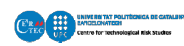

Regional

Degree of development of regional regulations and guidelines vary from one autonomic region to another

(O)

国

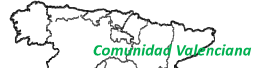

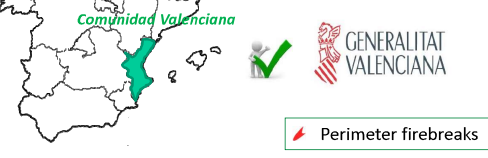

Less than $30 \%$ slope
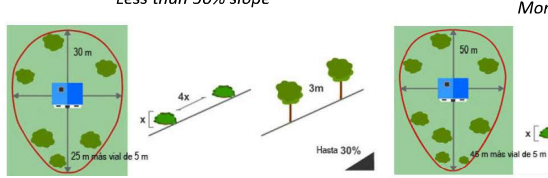

More than $30 \%$ slope

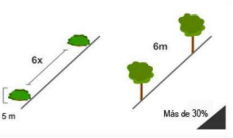

WUI FIRE MANAGEMENT IN SPAIN - Legal Framework

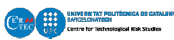

Regional

- Degree of development of regional regulations and guidelines vary from one autonomic region to another
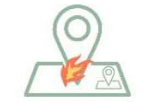

$\equiv$

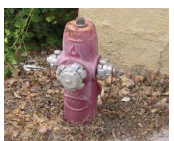

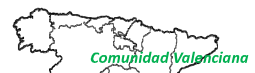

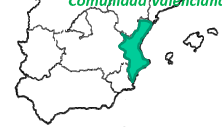

\section{GENERALITAT}

4 Maximum distance between hydrants of $200 \mathrm{~m}$

- 2 hydrants during 2 hours operating at $1020 \mathrm{l} / \mathrm{min} 1$ bar

+ $200 \mathrm{~m} 3$ water tanks, with a service area of $r=2.5 \mathrm{~km}$

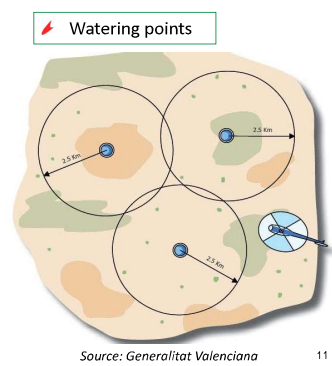

WUI FIRE MANAGEMENT IN SPAIN - Legal Framework

Regional Degree of development of regional regulations and guidelines vary from one autonomic region to another

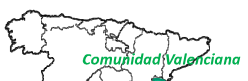

严

Minimum of 2 access roads in built-up areas

$45 \mathrm{~m}$ minimum width

+ $5 \mathrm{~m}$ free height

- And more: curved sections, sidings, etc.
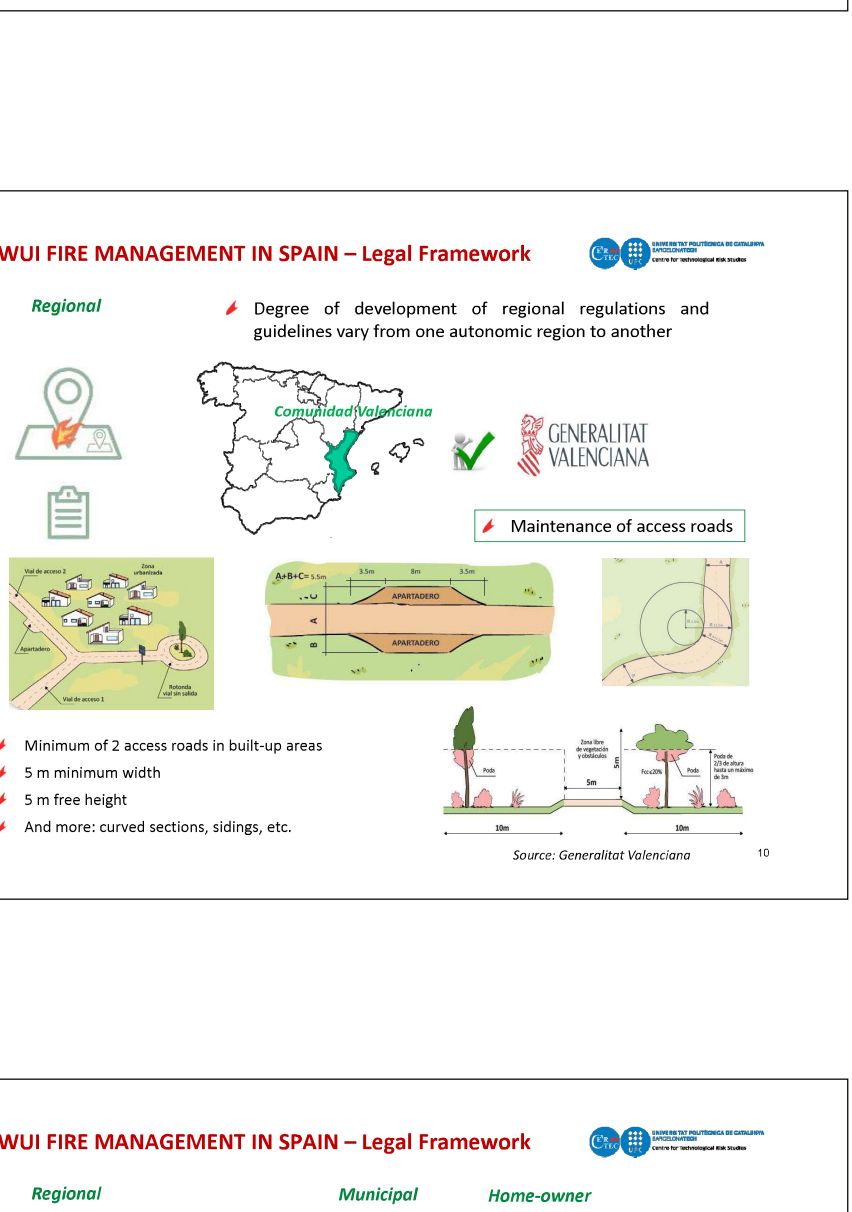

WUI FIRE MANAGEMENT IN SPAIN - Legal Framework 
WUI FIRE MANAGEMENT IN SPAIN - Legal Framework
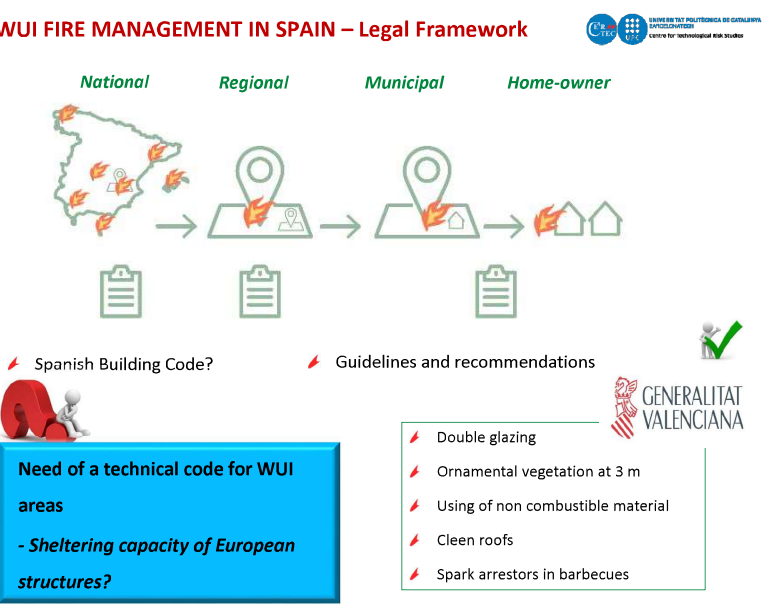

WUI FIRE MANAGEMENT IN SPAIN - Complience

Although Spain has legislation and high losses every year, the degree of compliance is

- Small towns: limited resources

Large towns: limited interest

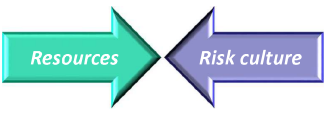

- Asturias, Galicia, Cantabria, Euskadi and the provinces of León and Zamora have the 52\% of the fires in Spain, but their fire management plans are deficient or very deficient (Greenpeace, 2018)
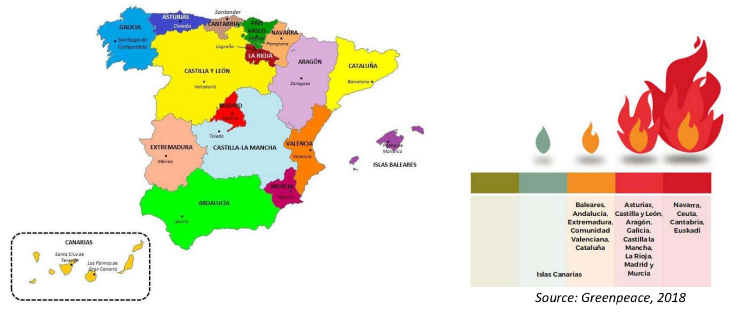

\section{NEEDS AND OPPORTUNITIES}

- Some of the regulations provided in the Spanish law are clearly insufficient both qualitative and quantitatively, particularly the design of perimeter firebreaks.

4 There is a clear need of a technical code for building and defense against forest fires in the WUI, to regulate, among others, the shelter capacity of typical Mediterranean houses.
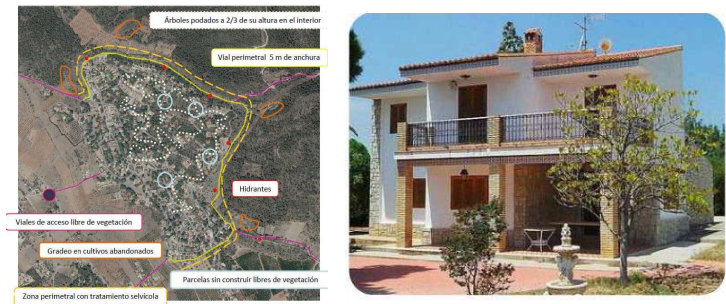

\section{NEEDS AND OPPORTUNITIES}

There is no regulation pointing at the installation, maintenance and defense of LPG tanks in the WUI. Negligence and regulatory gaps allow close exposure to flames from nearby fuels.
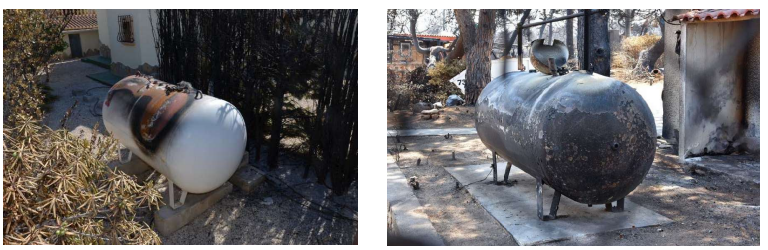

Benitatxell, València, Spain (2016) Source: David Caballero

Neos Voutzas-Mati, Greece (2018) Source: David Caballero
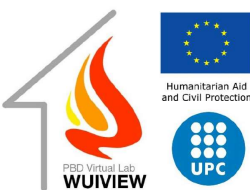

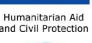

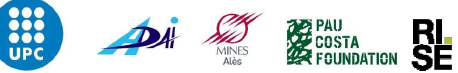

\title{
Thanks for your attention!
}

\author{
in elsa.pastor@upc.edu \\ yelsa_pastor \\ y @CERTEC_UPC \\ (6) certec.upc.edu
}

Acknowledgements: 
ISO TC92 workshop on

"Global Overview of Large Outdoor Fire Standards"

Organized in conjunction with ISO TC92 Task Group 03

7 October 2018 - Delft, Nederland

\section{"Large urban fires" in Japan \\ - History and management -}

Hideki Yoshioka ${ }^{1}$, Keisuke Himoto ${ }^{1}$,

Koji Kagiya², and Takeyoshi Tanaka ${ }^{3}$

${ }^{1}$ Senior Researcher, NILIM, Japan

${ }^{2}$ Chief Researcher, BRI, Japan

${ }^{3}$ Professor Emeritus, Kyoto University, Japan

\section{Contents}

- History and examples of "large urban fires".

- Standard regulations on "large urban fires".

- "City Planning Act", and "Building Standard Law".

- Brief introduction on "recent research projects".

- Summary

Large urban fires in Japan - History and management -
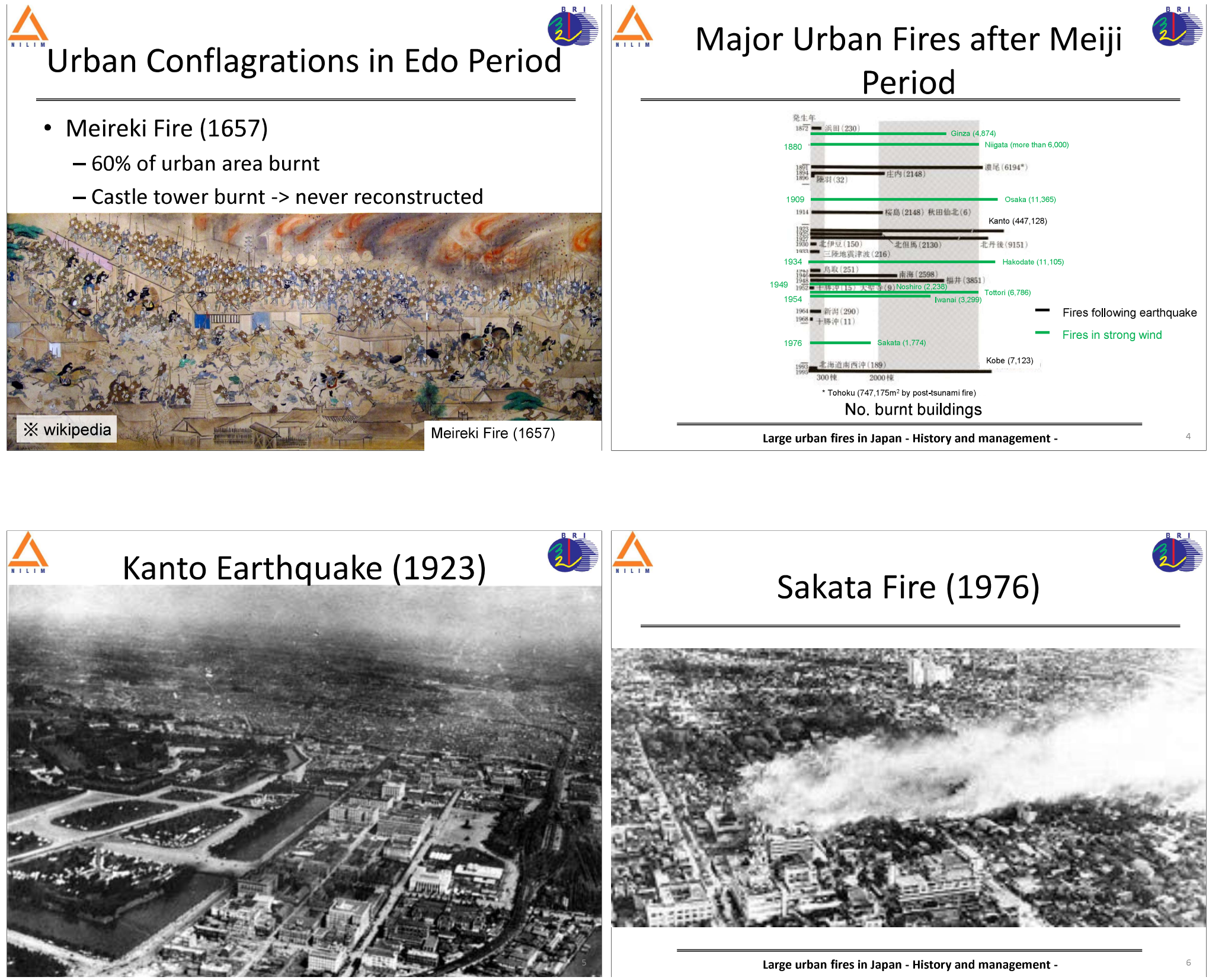

\section{Sakata Fire (1976)}

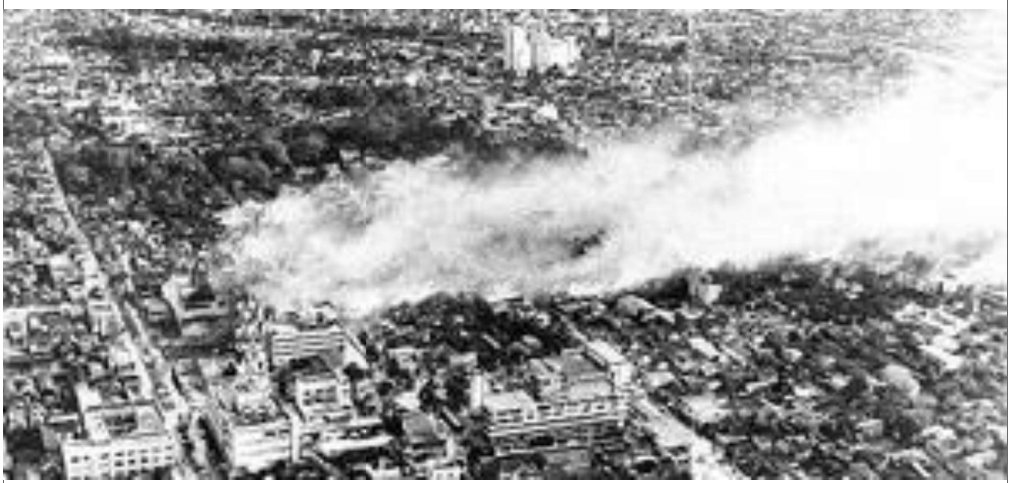

Large urban fires in Japan - History and management - 

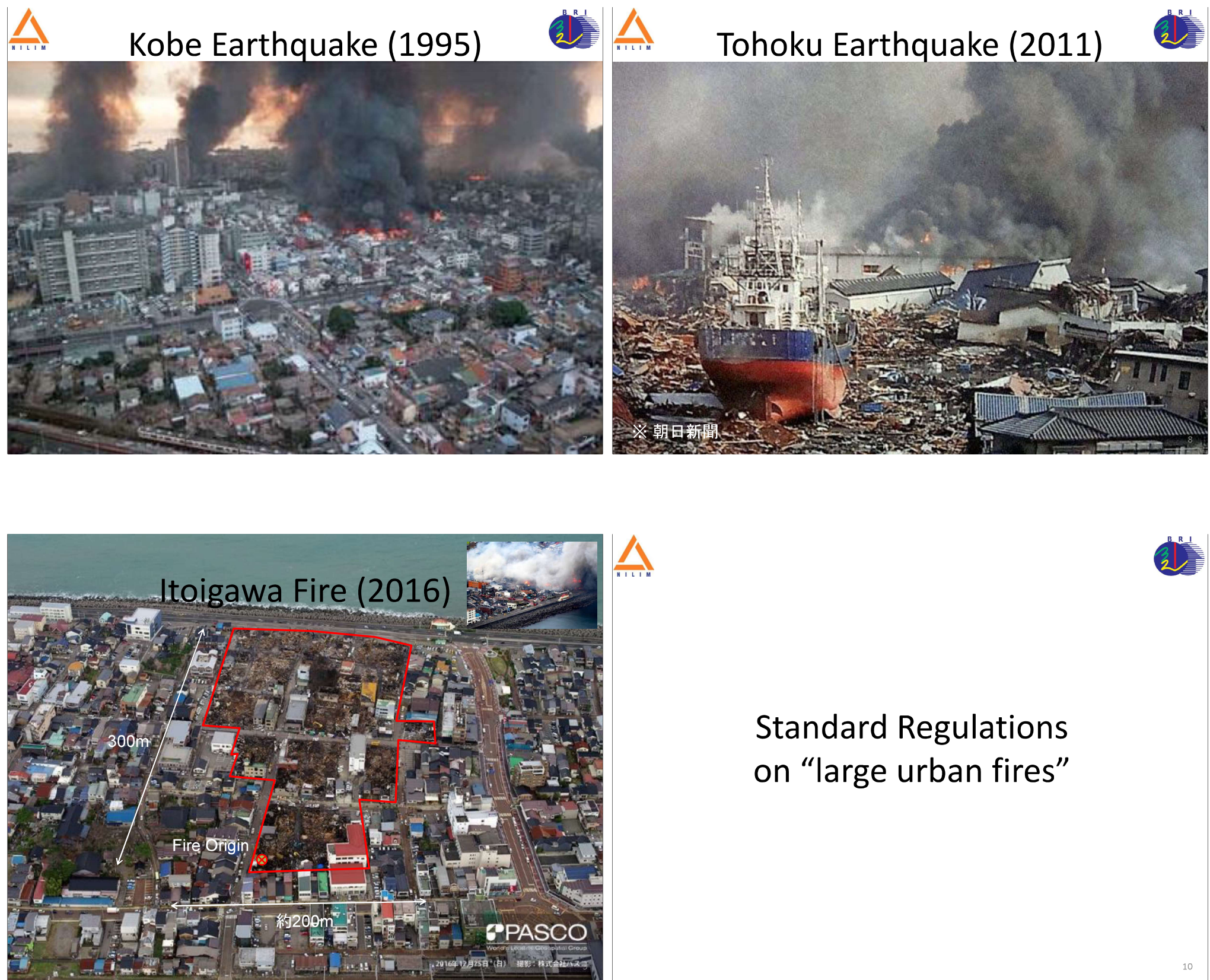
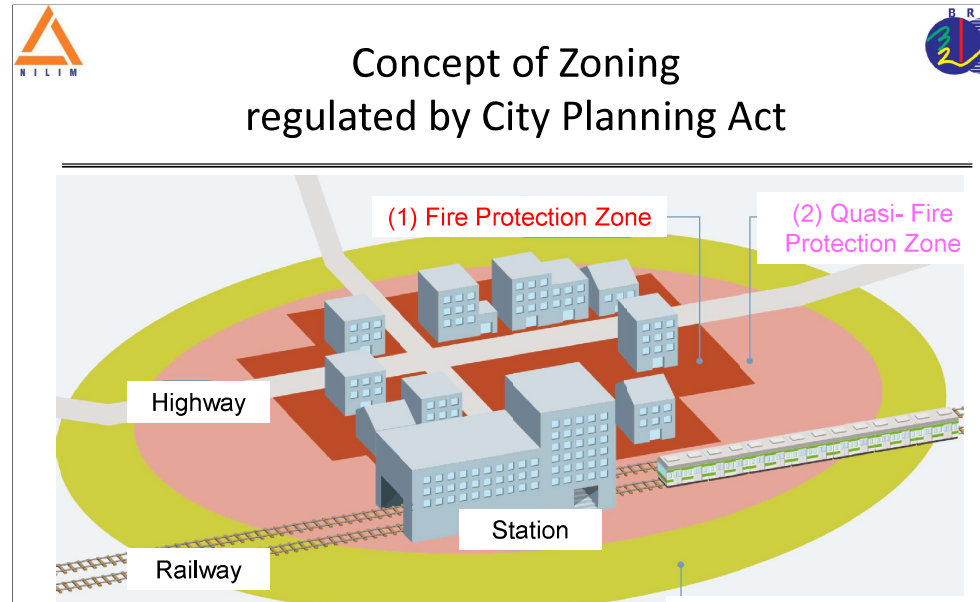

(3) Cities under Article 22 Non-combustible Roof Area
(4) Non-designated Area

Large urban fires in Japan - History and management -

\section{Standard Regulations on "large urban fires"}

\section{(1) Fire protection zone}

- According to Article 61 of BSL (Building Standard Law),

- buildings which have "three or more stories" or "whose total floor area exceeds $100 \mathrm{sq} \mathrm{m}$ " shall be "fire-resistive buildings".

- other buildings shall be either "fire-resistive buildings" or "quasi-fire-resistive buildings".

Large urban fires in Japan - History and management - 


\section{(2) Quasi-fire protection zone}

- According to Article 62 of BSL (Building Standard Law),

- buildings which have "four or more stories" or "whose total floor area exceeds 1,500 sq m" shall be "fire-resistive buildings".

- buildings "whose total floor area exceeds 500 sq $\mathrm{m}$ but does not exceed $1,500 \mathrm{sq} \mathrm{m}$ " shall be "quasi-fire-resistive buildings".

- buildings which have "three stories" be "quasifire-resistive buildings".

Large urban fires in Japan - History and management
(3) Cities under Article 22 of BSL "Non-combustible Roof Area"

According to Article 22 of BSL (Building Standard Law),

- The construction of roofs of buildings shall conform to technical criteria specified by Cabinet Order, according to the construction and the category of use of the building concerning the performance necessary for a roof to prevent the occurrence of a fire in the building caused by burning brands assumed to accompany a normal fire.

Large urban fires in Japan - History and management -

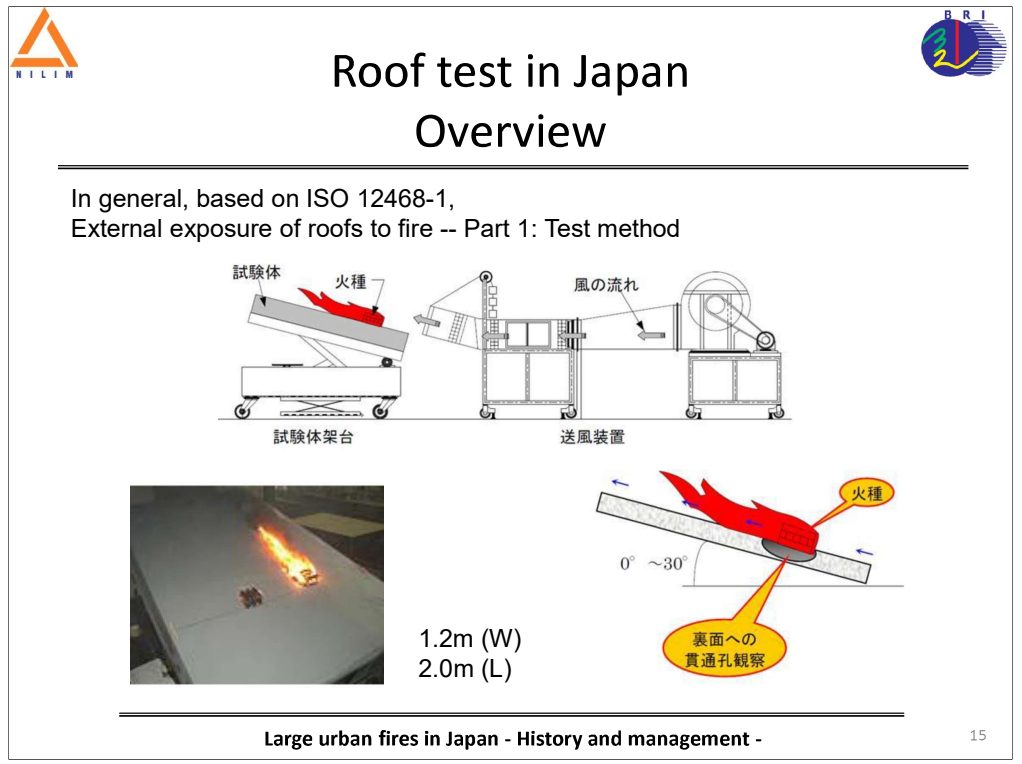

\section{Research Activities 1940-1960's}

- Fire spread rate due to wind speed

- Firebrand scattering and accumulation behavior

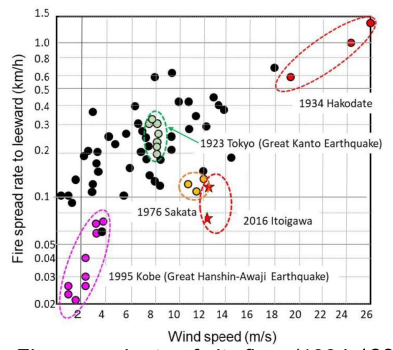

Fire spread rate of city fires (1934-1960's) incl. recent fires courtesy of Dr. Tokiyoshi Yamada

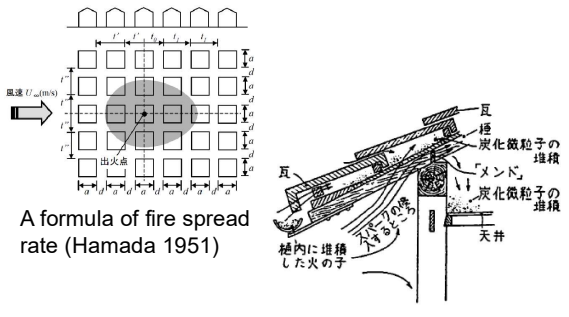

Accumulation of firebrand in a traditional Japanese wooden roof structure (Kamei 1960)

\section{Research Activities 1980-2000's}

- Comprehensive countermeasures against city fires

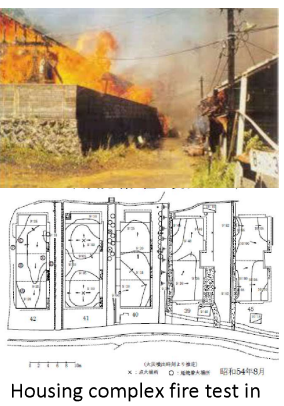

Saganoseki (1979)

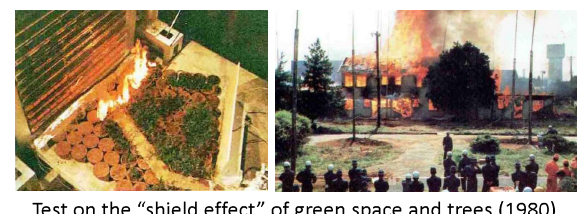

Test on the "shield effect" of green space and trees (1980)

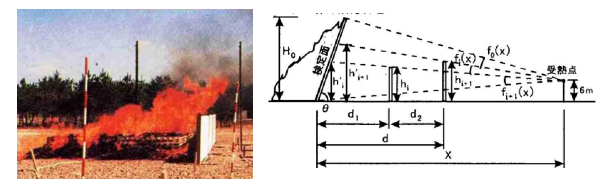

Comprehensive management technique of countermeasures (1982) Large urban fires in Japan - History and management 


\section{Research Activities 2000-}

- Fire dynamics of wind effect on large outdoor fires

- Detailed physical simulation model of city fire
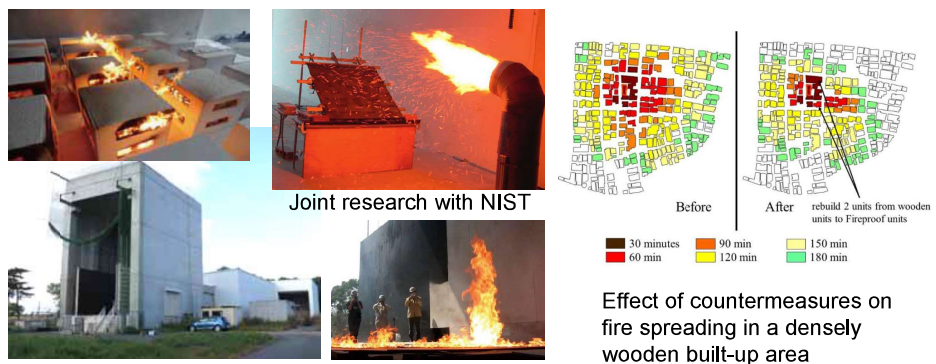

国 30 minutes $\square_{60}^{90 \min } \square_{120 \min }^{150 \mathrm{~min}}$

Effect of countermeasures on fire spreading in a densely wooden built-up area

Fire Research Wind Tunnel Facility (FRWTF) in BRI

Large urban fires in Japan - History and management -

\section{Limitation of the Current Regulationx}

- Uniform requirement for all the main building members including columns, beams, walls, floors, etc.

- Uniform requirement diminishes flexibility of building design

- Wooden members may be used as long as the entire building maintains safety equivalent to the current regulation?

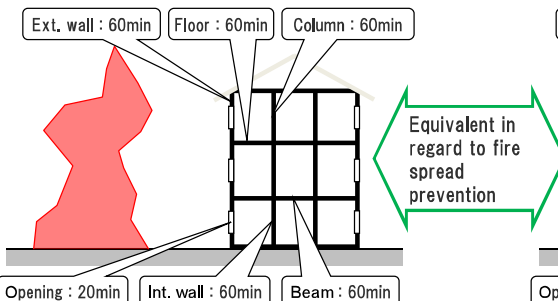

Ext. wall : 90min Floor : Wooden Column: Wooden

Opening : $20 \mathrm{~min}$ Int. wall : 60min Beam: 60min

Current regulation

Uniform recuirement for all main members

Large urban fires in Japan - History and management -

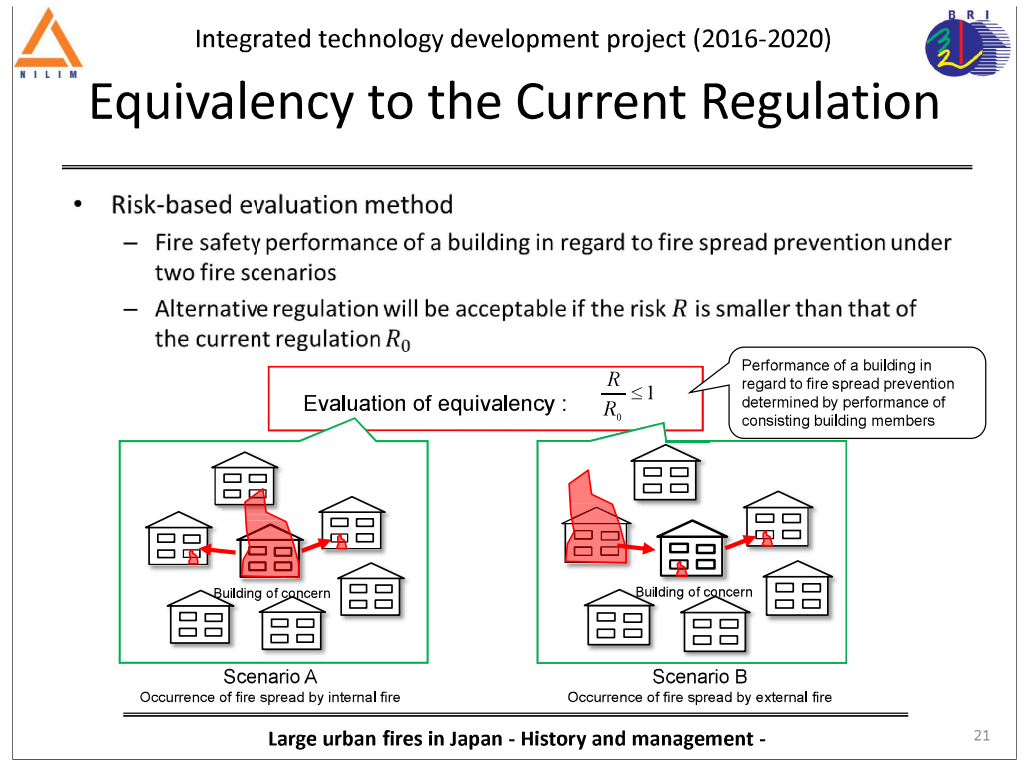

Application of JIS A 1310 (façade test): Fire spread to adjacent car
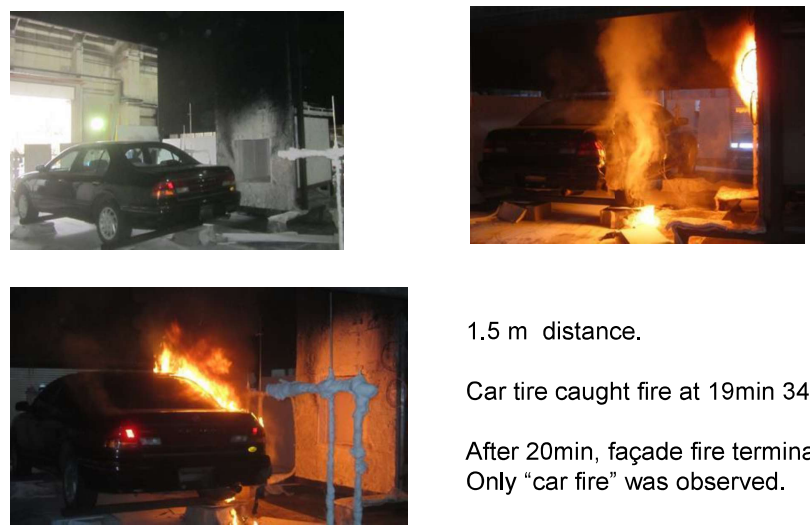

$1.5 \mathrm{~m}$ distance.

Car tire caught fire at $19 \mathrm{~min} 34 \mathrm{sec}$

After 20min, façade fire terminated Only "car fire" was observed.
Application of JIS A 1310 (façade test): Fire spread to adjacent building
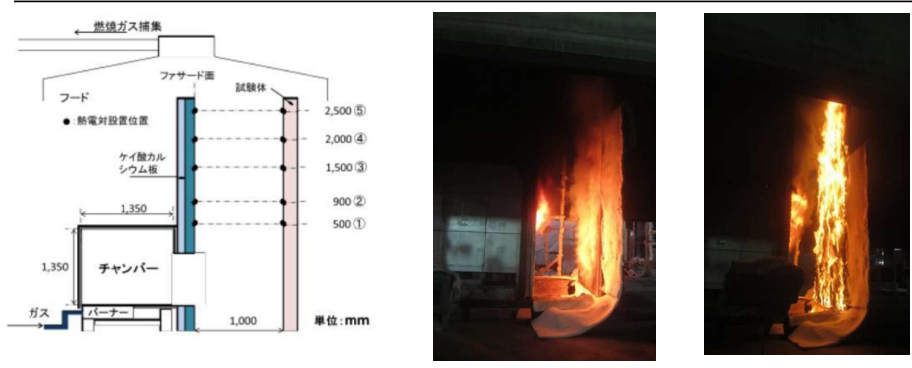

$1 \mathrm{~m}$ distance.

Plywood façade, as adjacent building.

$600 \mathrm{~kW}$, for first ten minutes.

No fire spread

$1,200 \mathrm{~kW}$, after ten minutes.
Fire spread soon after ten minutes.

\section{Summary}

- "Large urban fires" have overlapped area with "WUI fires" in the mechanism of fire spread via flying fire brands with convection and radiation, within the scope of "large outdoor fires".

- It is highly expected that int'I standardization work on "large outdoor fires and the built environment" could make a contribution to mitigating the loss caused by those large fires. 

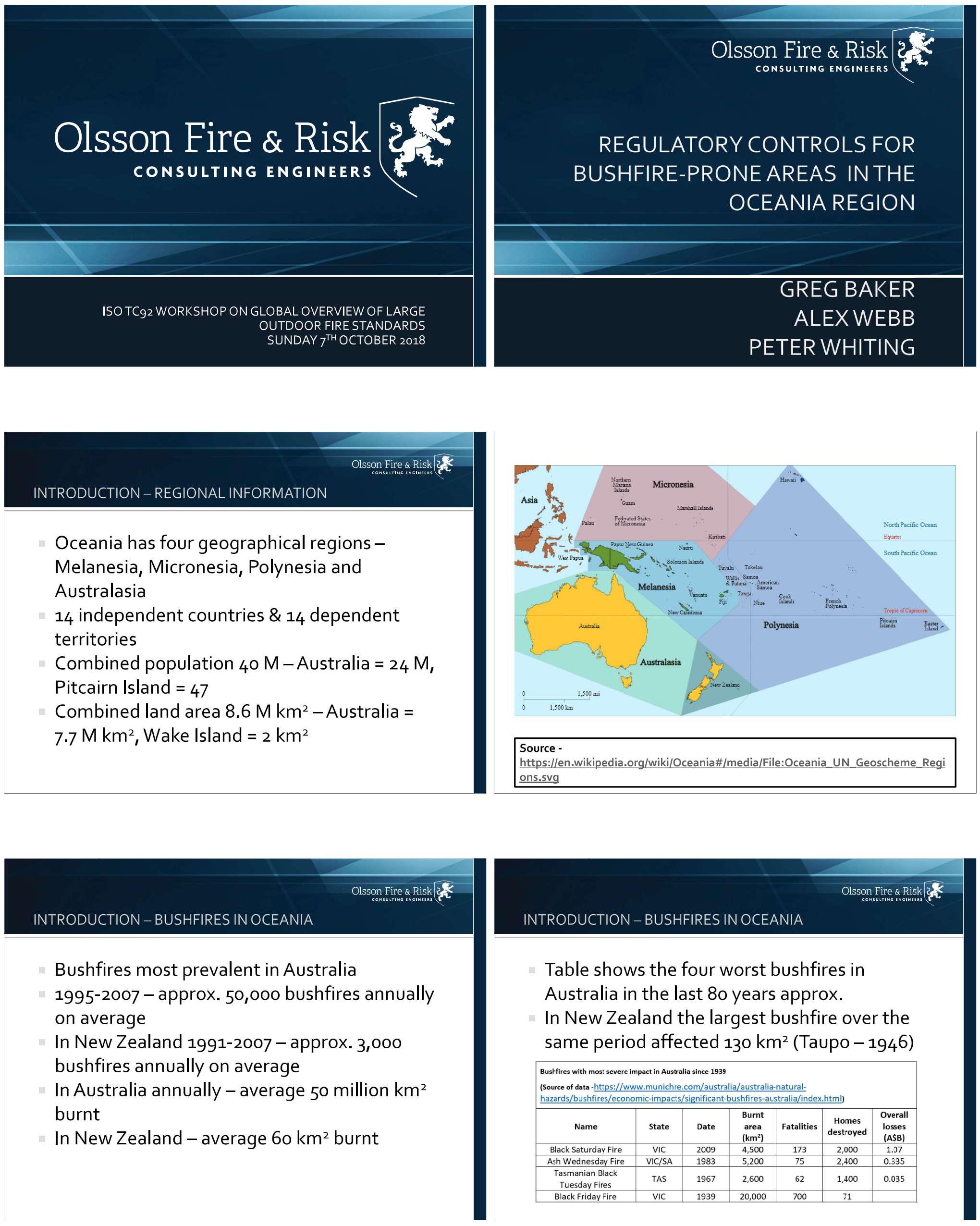
First scientific house-by-house research occurred after Beaumaris fire (VIC) in 1944 Results not promulgated until Ash Wednesday fire (VIC/SA) 1983

Larger studies were triggered -455 houses studies Mt Macedon and 1148 houses Otway Ranges

These latter studies formed basis for first Australian standards published in 1991
Australia and New Zealand have similar building regulatory regimes - performance-based NZ has no regulatory controls specific to bushfires Australia in contrast has very specific requirements

Australia's National Construction Code has performance provisions to mitigate impact on buildings in bushfire-prone areas

Hierarchy of objectives, functional statements and performance requirements directly address bushfire risk
AS 3959 is primary standard

Contains method to determine Bushfire Attack Level (BAL) for individual buildings

$B A L$ is measure of severity of buildings potential exposure to ember attack, radiant heat and direct flame contact

AS 3959 has six BALs - BAL-LOW, BAL-12.5, BAL-19, BAL-29, BAL-40 and BAL-FZ

The BAL for the particular building then determines the required construction

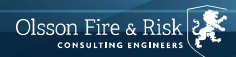

BAL is a function of four factors - fire danger index, vegetation type classification, distance from building site to vegetation, slope of land under vegetation

These four factors in combination determine the BAL - tabular method (simple) or calculation (detailed)

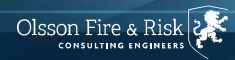

VEGETATION TYPE CLASSIFICATION

Seven vegetation classifications

Group A Forest, Group B Woodland, Group C

Shrubland, Group D Scrub, Group E

Malle/Mulga, Group F Rainforest, Group G

Grassland

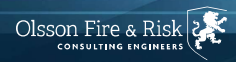

BUSHFIRE STANDARDS - TEST STANDARDS

AS 3959 contains prescriptive construction requirements for different BALs

Other option is to test construction system

AS 1530.8 .1 provides a method to determine performance of external construction element when exposed to radiant heat, burning embers and burning debris

Laboratory simulation for BAL-12.5 to BAL-40 of actual bushfire attack 
Construction exposed to a radiant heat profile Profile simulates passage of bushfire front Profile includes rapid heating phase, constant peak for 2 minutes and slow decay period Total radiant exposure lasts 10 minutes Radiating steel panel typically used Specimen moved progressively away from radiating panel during 10-minute exposure period
Burning embers considered as pilot ignition source on vertical and underside exposed horizontal surfaces - small gas flame Burning debris on upper surface of horizontal surfaces simulated by pre-ignited timber cribs

- The second test standard called up by AS 3959 is AS 1530.8.1

Deals with BAL-FZ

Test duration go minutes

Standard fire resistance test of specimen for 30 minutes

Specimen then removed from furnace and monitored for 60 minutes to ensure specimen is self-defending

Bushfire-resisting timber deemed to be acceptable to withstand up to BAL-29

Can be achieved:

- Inherent properties of timber

- Impregnation with fire-retardant chemicals

- Application of fire-retardant coating or substrate Cone calorimeter testing (plus accelerated weathering where timber altered)

\section{Olsson Fire \& Risk} CONSULTING ENGINEERS

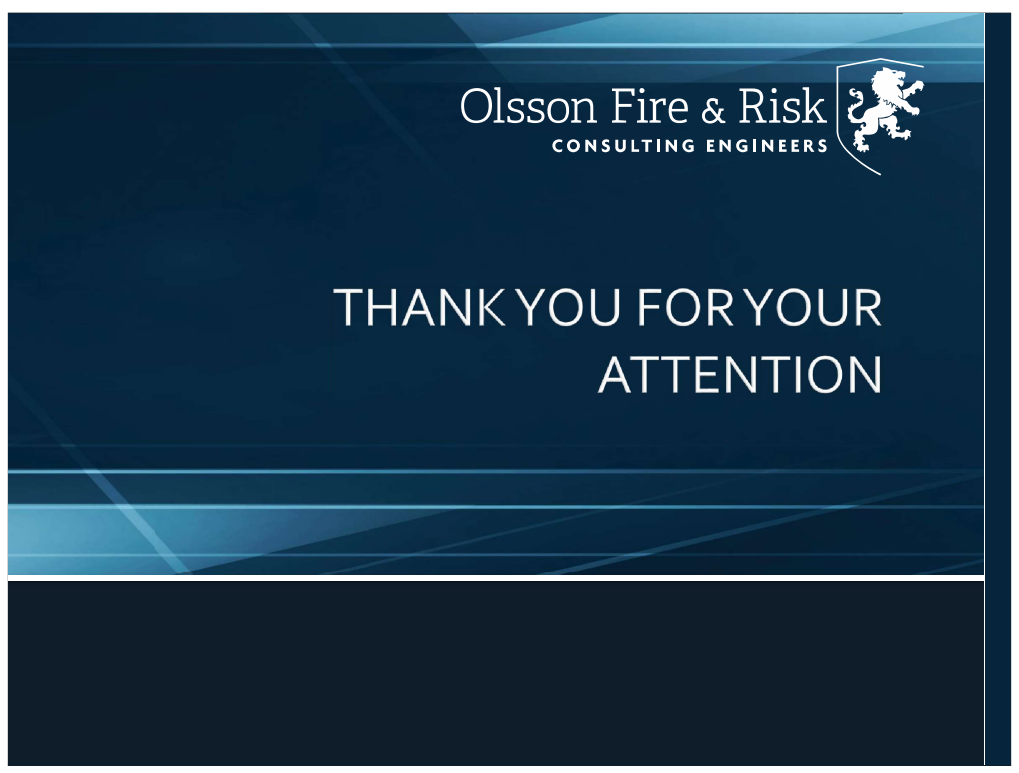

